REVIEW

\title{
Deep brain stimulation for dystonia
}

\author{
Marie Vidailhet, ${ }^{1,2,3}$ Marie-France Jutras, ${ }^{2}$ David Grabli, ${ }^{1,2,3}$ Emmanuel Roze ${ }^{1,2,3}$
}

${ }^{1}$ AP-HP, Department of Neurology, Groupe Hospitalier Pitié-Salpêtrière, Paris, France ${ }^{2}$ Centre de Recherche de I'Institut du Cerveau et de la Moelle épinière (CRICM), CNRS UMR 7225, UPMC Université Paris 6/Inserm UMR_S 975, Paris, France

${ }^{3}$ Pierre et Marie Curie-Paris-6 University, Paris, France

\section{Correspondence to} Professor Marie Vidailhet, Department of Neurology and UMRS 975, Salpêtrière Hospital, Boulevard de I'Hôpital, Paris 75013, France; marie.vidailhet@psl.aphp.fr

DG and ER contributed equally.

Received 11 June 2012 Accepted 15 October 2012 Published Online First 15 November 2012

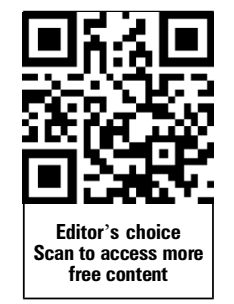

To cite: Vidailhet $M$, Jutras M-F, Grabli D, et al. J Neurol Neurosurg Psychiatry 2013;84: 1029-1042.

\section{ABSTRACT}

The few controlled studies that have been carried out have shown that bilateral internal globus pallidum stimulation is a safe and long-term effective treatment for hyperkinetic disorders. However, most recent published data on deep brain stimulation (DBS) for dystonia, applied to different targets and patients, are still mainly from uncontrolled case reports (especially for secondary dystonia). This precludes clear determination of the efficacy of this procedure and the choice of the 'good' target for the 'good' patient. We performed a literature analysis on DBS for dystonia according to the expected outcome. We separated those with good evidence of favourable outcome from those with less predictable outcome. In the former group, we review the main results for primary dystonia (generalised/focal) and highlight recent data on myoclonus-dystonia and tardive dystonia (as they share, with primary dystonia, a marked beneficial effect from pallidal stimulation with good risk/ benefit ratio). In the latter group, poor or variable results have been obtained for secondary dystonia (with a focus on heredodegenerative and metabolic disorders). From this overview, the main results and limits for each subgroup of patients that may help in the selection of dystonic patients who will benefit from DBS are discussed.

\section{INTRODUCTION}

Attempts to treat dystonia with functional surgery started in the early 50 s with lesions in various sites, including dentate nucleus, zona incerta, subthalamic nucleus and the two most common and most effective targets, the pallidum interna (GPi) and the thalamus. Partial to marked improvements were obtained, but the benefits were not always sustained and there was a risk of permanent disability. Deep brain stimulation (DBS) for dystonia was first described by Mundinger in $1977,{ }^{1}$ Benabid et al in $1987,{ }^{2}$ Krauss et $a l^{3}$ and Kumar et $a l^{4}$ in 1999, and Coubes $e t a l^{5}$ in 2000. A large number of patients have been successfully treated since then, but interpretation of the literature remains difficult because of differences across teams in terms of methodology (including surgical protocol), stimulation settings, evaluation and follow-up. Beyond technical considerations, the criteria for selection of patients, the age at the time of surgery, and the diversity and complexity of dystonia subtypes are also highly variable. This may account (at least partially) for the striking variability in responsiveness to DBS. The outcome of surgery in individual patients is hard to predict, particularly in the focal or secondary dystonias. Firm consensual recommendations for patient selection have been impossible to establish, except in a few situations, including generalised primary dystonia and severe cervical dystonia. The efficacy and safety of GPi-DBS have been well established in generalised ${ }^{6}$ or segmental $^{7} 8$ primary dystonia in large, well-designed multicentre trials. In addition to these primary dystonias, GPi-DBS has recently been demonstrated to be markedly effective in myoclonus-dystonia and tardive dystonia. ${ }^{9}$ In sharp contrast, the benefit of GPi-DBS for the secondary dystonias (such as dystonia-choreoathetosis cerebral palsy or inherited metabolic disorders) is still subject to debate. In order to help the clinician select the 'good' target for the 'good' patient at the right time with the best risk/benefit ratio, we have reviewed the published literature, focusing on patient outcome, and separated the subtypes of dystonia with good predictive factors, ${ }^{10}$ which are most likely to produce good improvement including better quality of life, from those with less predictable or less favourable outcome.

\section{METHODS}

The PubMed database was searched for articles describing DBS for dystonia. Keywords were 'dystonia', 'DBS', 'choreoathetosis', 'cerebral palsy' pallidum, GPi, thalamus and subthalamic nucleus. Only publications written in English and reporting individual clinical outcome data were included in the review. When patients were mentioned in multiple overlapping publications, we compiled the data for the same patient and mentioned it in the table. Instead of following the classical dichotomy between primary and secondary dystonia, we chose to present the literature analysis according to the expected outcome (decision-making support). We separated those with good evidence of favourable outcome from those with less predictable outcome. Dystonia with features of parkinsonism were excluded. Dystonia subtypes are primary, dystonia plus (dystonia-parkinsonism was excluded) and secondary dystonia (with focus on tardive dystonia, status dystonicus and dystonia-choreoathetosis cerebral palsy). In primary dystonia, results are reported according to body distribution (generalised, segmental/cervical and cranial).

\section{LITERATURE ANALYSIS ACCORDING TO THE EXPECTED OUTCOME \\ Dystonia with good evidence of favourable outcome}

This group is heterogeneous and includes primary dystonia, myoclonus-dystonia (dystonia-plus syndrome category) and tardive dystonia (secondary dystonia category). Improvements of $50-60 \%$ were generally observed, with some patients experiencing as much as a $90 \%$ reduction in severity and 
disability on the Burke-Fahn-Marsden (BFM) dystonia scale with concomitant improvement in the quality of life. Beyond their differences, these different types of dystonia share the common feature of being 'functional' (eg, non-lesional) in contrast with secondary lesional dystonia, the latter often having abnormal MRI scans.

Specificities, long-term follow-up and predictive factors of outcome (if known) are detailed for each type of dystonia (primary dystonia, myoclonus-dystonia and tardive dystonia).

\section{Primary dystonia}

\section{Generalised and segmental/cervical dystonia}

To date, experience with GPi stimulation has been reported in more than 200 patients with primary dystonia in reviews, ${ }^{9-16}$ for patients with DYT1 mutations, ${ }^{5-7} \quad 13 \quad 14 \quad 17-25 \quad 16$ and in

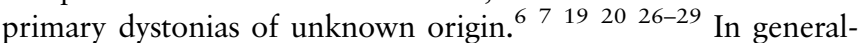
ised $^{67}$ and segmental ${ }^{7}$ dystonia, a good risk/benefit ratio has been demonstrated by two multicentre studies, ${ }^{6} 7$ with mean improvements in the dystonia motor score of $51 \%{ }^{6}$ and $42 \%$ (double-blind) ${ }^{7}$ with little placebo effect. ${ }^{7}$ GPi-DBS has also been shown to be effective in segmental dystonia with cervical involvement, ${ }^{7} \quad 8 \quad 29$ 30-35 including in some large multicentre studies. ${ }^{8} 2429$ The first prospective, single-blind, multicentre study assessing the efficacy and safety of bilateral GPi-DBS in cervical dystonia demonstrated a 55\% improvement in dystonia on the Toronto Western Spasmodic Torticollis Rating Scale. The Toronto group defined a good response as a $50 \%$ or greater improvement. Pain, general health, physical functioning and depression scores also improved significantly. ${ }^{8}$ Stimulation with a smaller pulse width $(71 \mu \mathrm{s})^{8}$ or a larger pulse width $(219 \mu \mathrm{s})^{36}$ gave similar results. The magnitude of improvement increased to $70 \%$ in a recent blinded study ${ }^{37}$ with a median follow-up of 30 months. However, poor to no response was still rarely observed, although these patients differed in neither the clinical pattern of dystonia ${ }^{36}$ nor the therapeutic position of the therapeutic contacts (adequate placement) ${ }^{37}$ from those who did respond.

Although there is unpublished experience dating back almost 20 years, the longest published follow-up of patients undergoing GPi-DBS is 8 years $^{25}$ with an excellent outcome and sustained benefit in primary dystonia and up to 10 years (mean follow-up duration 6.2 years, range 3-10 years) in DYT1-positive patients. ${ }^{14}$ After 5 years, eight of these 26 patients required a second implantation because of worsening of dystonic symptoms. They were preoperatively indistinguishable from those who had a good and stable improvement after the primary procedure. However, the outcome was different in those who received an additional lead: four subsequently improved, although without reaching the previous optimal benefit, but the other four did not improve much, although neither did they relapse back to preoperative status. ${ }^{38}$ Increasing the number of activated contacts and/or the voltage did not always provide additional improvement or control of all the signs in patients who respond well to therapy.

\section{Other focal dystonia (cranial and upper limb)}

Apart from cervical dystonia, the data regarding other forms of focal dystonia are limited to small series of mixed cases or individual reports and should be interpreted with caution, as some patients showed excellent improvement (up to 70\%) ${ }^{38-40}$ and others had little or no benefit. ${ }^{41}$ In most cases, bilateral GPi stimulation was used. When staged implantation was performed, the best improvements were obtained when the second electrode was implanted. ${ }^{42}$ In patients who improve insufficiently after treatment with botulinum toxin, DBS can be an acceptably effective therapy, ${ }^{43}$ but the risk of the procedure has to be cautiously weighed against the benefit in these focal (and less severe) dystonias.

\section{Cranial dystonia}

Good results have been reported in blepharospasm and Meige syndrome (table 1). $.^{28} \quad 3042 \quad 44-50$ Blepharospasm improved in most patients, but the results on speech and swallowing were not so good. ${ }^{41}$ In a homogeneous series of patients with craniocervical and brachial segmental dystonia with oromandibular involvement, ${ }^{51}$ there was little effect on speech/swallowing scores at 6 months, but there was an improvement in function at 3 years follow-up $(60 \%)$ even in patients who were almost anarthric before the procedure. ${ }^{51}$ This pattern of improvement as a function of site accords with results previously reported in generalised dystonia.

Beneficial effects could be obtained with low stimulation intensity $(1.5 \mathrm{~V}, 90 \mu \mathrm{s}, 130 \mathrm{~Hz}),{ }^{49}$ lower frequency $(100 \mathrm{~Hz})^{41}$ or cyclic stimulation mode, with the stimulator being programmed to turn off automatically during nighttime sleep. ${ }^{40}$ Sustained long-term benefit was observed on follow-up of $49 \pm$ 43.7 (mean \pm SD) months. ${ }^{49} 5153$

In addition, surgery in cranial or craniocervical dystonia may give the opportunity to observe the effect of bilateral GPi stimulation on unaffected parts of the body: as the dystonia improves, motor function worsens in previously non-dystonic regions, with slowing of movement and difficulties with typing, handwriting or balance. ${ }^{45}$

\section{Upper limb dystonia}

Severe writer's cramp is rare, but patients with it have been successfully treated with unilateral DBS of the ventral oral (Vo) nucleus of the thalamus. ${ }^{60}{ }^{61}$ This unusual target was chosen on the basis of encouraging results with unilateral thalamotomy in the Vo complex. ${ }^{62} 63$ In addition, bilateral stimulation of the ventral intermediate nucleus of the thalamus (Vim) has been successful in three cases of dystonic tremor. ${ }^{64}$ However, in segmental or focal dystonia mainly involving the upper limbs or lower face, a decrease in the severity of dystonia is not meaningful without consistent improvement in hand function or speech. To date, this question has not been specifically addressed. The encouraging results with DBS in focal or segmental dystonia (except for severe cervical involvement) reported in case series have yet to be confirmed in larger studies. Beneficial effects have also been reported in axial dystonia, ${ }^{65} \operatorname{limb}$ dystonia $^{63} 66$ and hip dystonia. ${ }^{67}$

\section{Predictive factors of outcome in primary dystonia Age}

From retrospective series, it appears that younger age at the time of surgery $(<21$ years old) and shorter duration of symptoms ( $<15$ years) are the main predictive factors of good postoperative outcome at 1 and 3 years. ${ }^{25} 6869$ Age at onset and severity of the disease have little or no significant influence.

\section{Genetic status}

DYT1-positive status was independently associated with significantly greater improvement after surgery, ${ }^{10}{ }^{70}$ but this is still controversial. $^{24}$ Recent long-term follow-up data on DYT1 mutation carriers suggest a possible secondary failure of DBS, challenging the assumption of DYT1 mutations being a predictor of a beneficial clinical outcome. Worsening of symptomatology may be related to symptom spread (progressive disorder), with 
Table 1 Blepharospasm and Meige syndrome

\begin{tabular}{|c|c|c|c|c|c|c|}
\hline Reference & $\begin{array}{l}\text { Age at surgery } \\
\text { (years), } \\
\text { mean (range) }\end{array}$ & $\begin{array}{l}\text { Disease duration } \\
\text { (years), } \\
\text { mean (range) }\end{array}$ & Surgery & $\begin{array}{l}\text { Stimulation } \\
\text { parameters (R/L), } \\
\text { mean (range) }\end{array}$ & $\begin{array}{l}\% \text { Improvement } \\
\text { at lastF/U (range) }\end{array}$ & $F / U$ \\
\hline $\begin{array}{l}\text { Limotai et } a{ }^{41} \\
\mathrm{n}=6\end{array}$ & $56.3(26-68)$ & $11.3(5-19)$ & GPi bilat & $\begin{array}{l}2.52 \mathrm{~V}(1.8-3.2) / 2.75 \mathrm{~V}(1.5-3.5) \\
282 \mu \mathrm{s}(60-450) / 265 \mu \mathrm{s}(60-450) \\
140 \mathrm{~Hz}(10-185) / 127 \mathrm{~Hz}(10-185)\end{array}$ & $\begin{array}{l}\text { BFM (mov) } \\
\quad 61.8 \%(16.6-100 \%) \\
\text { Blepharospasm improved in all patients } \\
\text { No improvement in speech and swallowing }\end{array}$ & 12 months \\
\hline $\begin{array}{l}\text { Reese et }\left.a\right|^{52} \\
\mathrm{n}=12\end{array}$ & $64.5(57-72)$ & $8.6(4-18)$ & GPi bilat & $\begin{array}{l}3.8 \mathrm{~V}(2.4-5.0) / 3.7 \mathrm{~V}(2.2-5.0) \\
143 \mu \mathrm{s}(60-210) / 145 \mu \mathrm{s}(90-210) \\
170 \mathrm{~Hz}(130-235)\end{array}$ & $\begin{array}{l}\text { BFM (mov) } \\
\text { FU1/FU2 } \\
45 \% / 53 \% \\
\text { Subscores } \\
\text { Eyes } 38 \% / 47 \% \\
\text { Mouth } 50 \% / 56 \% \\
\text { Speech } 44 \% / 64 \%\end{array}$ & $\begin{array}{l}\text { FU1 } \\
4.4 \pm 1.5 \text { months } \\
\text { FU2 } \\
38 \pm 21.7 \text { months }\end{array}$ \\
\hline $\begin{array}{l}\text { Sako et } a f^{53} \\
\mathrm{n}=5\end{array}$ & $65(54-72)$ & $12(7-18)$ & GPi bilat & $\begin{array}{l}2.6 \mathrm{~V}(1.0-3.9) / 2.5 \mathrm{~V}(1.0-3.6) \\
392 \mu \mathrm{s}(210-450) \\
84 \mathrm{~Hz}(60-130)\end{array}$ & $\begin{array}{l}\text { BFM (mov) } \\
84 \%(75-94 \%) \\
\text { BFM (dis) } \\
89 \%(80-100 \%)\end{array}$ & $49 \pm 43.7$ months \\
\hline $\begin{array}{l}\text { Tai et } a l^{40} \\
\mathrm{n}=1\end{array}$ & 66 & 3 & GPi bilat & $\begin{array}{l}2.2-3.2 \mathrm{~V} / 2.2-3.2 \mathrm{~V} \\
450 \mu \mathrm{s} \\
60 \mathrm{~Hz}\end{array}$ & $\begin{array}{l}\text { BFM (mov) } \\
75 \% \\
{ }^{*} \text { continuous mode until } 24 \text { months } \\
\text { cycling mode } 34-60 \text { months }\end{array}$ & 60 months \\
\hline $\begin{array}{l}\text { Ghang et } a l^{50} \\
\mathrm{n}=11\end{array}$ & $58.3(45-70)$ & $8.7(1-20)$ & GPi bilat & $\begin{array}{l}3.4 \mathrm{~V}(2.6-5.0) \\
133.6 \mu \mathrm{s}(60-210) \\
143.1 \mathrm{~Hz}(60-185)\end{array}$ & $\begin{array}{l}\text { BFM (mov) at } 12 \text { months } \\
74.5 \% \\
\text { Subscores } \\
\text { Eyes } 63.3 \% \\
\text { Mouth } 80.9 \% \\
\text { Speech } 68.4 \% \\
\text { Neck } 87.9 \% \\
\text { BFM (mov) at } 24 \text { months }(n=5) \\
85.5 \%\end{array}$ & $23.1 \pm 6.4$ months \\
\hline \multirow[t]{3}{*}{$\begin{array}{l}\text { Lyons et } a l^{47} \\
\mathrm{n}=3\end{array}$} & 73 & $\mathrm{~N} / \mathrm{A}$ & GPi bilat & $\begin{array}{l}2.4 \mathrm{~V} / 2.8 \mathrm{~V} \\
90 \mu \mathrm{s} \\
145 \mathrm{~Hz}\end{array}$ & $\begin{array}{l}\text { BFM (mov) } \\
\quad 82 \%\end{array}$ & 54 months \\
\hline & 63 & $\mathrm{~N} / \mathrm{A}$ & GPi bilat & $\begin{array}{l}3.6 \mathrm{~V} / 3.0 \mathrm{~V} \\
120 / 60 \mu \mathrm{s} \\
60 / 90 \mathrm{~Hz}\end{array}$ & $50 \%$ & 42 months \\
\hline & 56 & N/A & GPi bilat & $\begin{array}{l}3.0 \mathrm{~V} / 3.0 \mathrm{~V} \\
120 \mu \mathrm{s} \\
130 \mathrm{~Hz}\end{array}$ & $79 \%$ & 48 months \\
\hline $\begin{array}{l}\text { Markaki et a } a^{18} \\
\mathrm{n}=1\end{array}$ & 49 & 7 & GPi bilat & $\begin{array}{l}2.6 \mathrm{~V} / 2.6 \mathrm{~V} \\
210 \mu \mathrm{s} \\
185 \mathrm{~Hz}\end{array}$ & $\begin{array}{l}\text { BFM (mov) } \\
70 \% \\
\text { BFM (dis) } \\
93 \%\end{array}$ & 6 months \\
\hline $\begin{array}{l}\text { Inoue et } a l^{54} \\
\mathrm{n}=1\end{array}$ & 61 & 18 & GPi bilat & $\begin{array}{l}3.9 \mathrm{~V} / 3.6 \mathrm{~V} \\
450 \mu \mathrm{s} \\
60 \mathrm{~Hz}\end{array}$ & $\begin{array}{l}\text { BFM (mov) } \\
86 \% \\
\text { BFM (dis) } \\
83 \%\end{array}$ & 10 years \\
\hline $\begin{array}{l}\text { Romito et } a l^{49} \\
\mathrm{n}=1\end{array}$ & 68 & 12 & GPi bilat & $\begin{array}{l}1.3 \mathrm{~V} / 1.3 \mathrm{~V} \\
90 / 90 \mu \mathrm{s} \\
130 / 130 \mathrm{~Hz}\end{array}$ & $\begin{array}{l}\text { BFM (mov) } \\
\text { Subscores } \\
\text { Eyes } 100 \% \\
\text { Mouth } 100 \% \\
\text { Speech } 100 \% \\
\text { TWSTRS } \\
\text { 93\% }\end{array}$ & 38 months \\
\hline $\begin{array}{l}\text { Blomstedt et } a P^{55} \\
\mathrm{n}=1\end{array}$ & 45 & 19 & GPi bilat & $\begin{array}{l}5.2 \mathrm{~V} / 4.9 \mathrm{~V} \\
120 \mu \mathrm{s} \\
145 \mathrm{~Hz}\end{array}$ & $\begin{array}{l}\text { BFM (mov) } \\
\quad 71.5 \%\end{array}$ & 18 months \\
\hline $\begin{array}{l}\text { Ostrem et al }{ }^{45} \\
\mathrm{n}=6\end{array}$ & $62(52-70)$ & $8.2(2-20)$ & GPi bilat & $\begin{array}{l}3.8 \mathrm{~V}(3.2-5.0) / 3.65 \mathrm{~V}(2.9-5.0) \\
205 \mu \mathrm{s}(180-210) / 190 \mu \mathrm{s}(90-210) \\
172 \mathrm{~Hz}(145-185)\end{array}$ & $\begin{array}{l}\text { BFM (mov) } \\
72 \% \text { Subscores } \\
\text { Eyes } 78.5 \% \\
\text { Mouth } 73.3 \% \\
\text { Speech } 48 \% \\
\text { TWSTRS } \\
54 \%\end{array}$ & 6 months \\
\hline $\begin{array}{l}\text { Opherk et } a l^{56} \\
\mathrm{n}=1\end{array}$ & 65 & $N / A$ & GPi bilat & $\mathrm{N} / \mathrm{A}$ & $\mathrm{N} / \mathrm{A}$ & 4 months \\
\hline $\begin{array}{l}\text { Houser and Waltz } \\
n=1\end{array}$ & 46 & 2 & GPi bilat & $\begin{array}{l}3.8 \mathrm{~V} / 2.6 \mathrm{~V} \\
210 \mu \mathrm{s} \\
160 \mathrm{~Hz}\end{array}$ & $\begin{array}{l}\text { BFM (mov) } \\
75 \%\end{array}$ & 6 months \\
\hline
\end{tabular}


Table 1 Continued

\begin{tabular}{|c|c|c|c|c|c|c|}
\hline Reference & $\begin{array}{l}\text { Age at surgery } \\
\text { (years), } \\
\text { mean (range) }\end{array}$ & $\begin{array}{l}\text { Disease duration } \\
\text { (years), } \\
\text { mean (range) }\end{array}$ & Surgery & $\begin{array}{l}\text { Stimulation } \\
\text { parameters (R/L), } \\
\text { mean (range) }\end{array}$ & $\begin{array}{l}\% \text { Improvement } \\
\text { at lastF/U (range) }\end{array}$ & $F / U$ \\
\hline & & & & & $\begin{array}{l}\text { UDRS } \\
\quad 85 \%\end{array}$ & \\
\hline $\begin{array}{l}\text { Foote et } a l^{42} \\
n=1\end{array}$ & 47 & 5 & GPi bilat & $\begin{array}{l}2.5 \mathrm{~V} / 3.3 \mathrm{~V} \\
450 \mu \mathrm{s} \\
185 \mathrm{~Hz}\end{array}$ & $\begin{array}{l}\text { UDRS } \\
\qquad \text { Eyes } 57 \% \\
\text { Lower face } 83 \%\end{array}$ & 15 months \\
\hline $\begin{array}{l}\text { Capelle et } a l^{57} \\
n=1\end{array}$ & 60 & 5 & & $\begin{array}{l}4.3 \mathrm{~V} / 4.3 \mathrm{~V} \\
210 \mu \mathrm{s} \\
130 \mathrm{~Hz}\end{array}$ & $\begin{array}{l}\text { BFM (mov) } \\
\text { Subscores } \\
\text { Eyes } 92 \% \\
\text { Mouth } 75 \% \\
\text { Speech 33\% }\end{array}$ & 24 months \\
\hline $\begin{array}{l}\text { Vercueil et } a l^{58} \\
n=1\end{array}$ & 59 & 15 & GPi bilat & N/A & $\begin{array}{l}\text { BFM (mov) } \\
66 \%\end{array}$ & 6 months \\
\hline $\begin{array}{l}\text { Muta et } a l^{59} \\
\mathrm{n}=1\end{array}$ & 61 & 18 & GPi bilat & $\begin{array}{l}3.6 \mathrm{~V} / 3.6 \mathrm{~V} \\
500 \mu \mathrm{s} \\
60 \mathrm{~Hz}\end{array}$ & $\begin{array}{l}\text { BFM (mov) } \\
\quad 80 \%\end{array}$ & N/A \\
\hline
\end{tabular}

an additional improvement after the second surgery (additional pair of electrodes). ${ }^{14}$

It is difficult to predict the influence of the DYT6 genetic status, but the topographical specificity of patients with THAP1 mutations (eg, severe cranial involvement) may be critical. Four patients with segmental or generalised dystonia and oromandibular and laryngeal involvement were treated with bilateral GPi stimulation, with moderate to good response on motor function but marginal benefit on speech, ${ }^{71}{ }^{72}$ suggesting that the site of the dystonia (oromandibular) influences functional prognosis more than genetic status.

\section{Cortical plasticity}

Interindividual differences (endophenotype), such as the levels of cortical plasticity, may play a role in the beneficial effect of DBS. $^{73} 74$

In rare cases, and after several years of stimulation, sustained relief ( $>1$ year) persisting after cessation of DBS has been observed in cervical dystonia ${ }^{62}$ and blepharospasm, ${ }^{75}$ suggesting that DBS therapy may have the capacity to induce plastic change, which lessens or obviates the need for further treatment in susceptible patients. ${ }^{75}$ In controlled studies with blind evaluation of the effects after the stimulator was switched off, the persistence of the beneficial effect was shorter and patients relapsed to their preoperative dystonia score after $30 \mathrm{~h}^{76}$

\section{Orthopaedic complications}

Fixed skeletal deformities ${ }^{77}$ or cervical myelopathy ${ }^{78} 79$ may also be associated with a poorer outcome. Myelopathy should be sought from the third decade of life onwards, especially in patients with severe neck dystonia (BFM motor score for the neck >4). Gait disorders and falls, wasting of hand muscles, and bladder dysfunction were the best clinical predictors of cervical myelopathy. ${ }^{78}$

\section{Optimal placement of electrodes}

Posteroventral GPi stimulation provides the best overall effect and is superior for the arm and trunk. Anterodorsal stimulation has equivalent efficacy for the leg. ${ }^{80}$ External globus pallidus (GPe) stimulation may be harmful, with lack of improvement or even worsening of dystonia. ${ }^{81}$ This effect is even more important in secondary dystonia such as dystoniachoreoathetosis cerebral palsy. ${ }^{82}$ Among the factors that influence the clinical outcome, the optimal placement of the electrodes within the pallidum seems the most critical, but is probably not the only one. Patients with optimally placed electrodes may still have a suboptimal response, and in this situation either additional electrodes ${ }^{38}$ or an alternative target ${ }^{83}$ should be considered. These authors also focused on brain imaging data and modelling the distribution of electrical current. Their predictive model suggested that (i) the greater the volume of the right GPi and (ii) the greater the volume of stimulated tissue within the left $\mathrm{GPi}$, the greater the postoperative improvement. ${ }^{8485}$

\section{Myoclonus-dystonia}

Experience with fewer than 30 patients has been published to date (table 2). Myoclonus dystonia (M-D) is a rare form of movement disorder, with prominent action myoclonus and slight dystonia. By far the most common forms of dystonia in patients with M-D are cervical dystonia and writer's cramp. Although genetically heterogeneous, many cases are caused by point mutations or large deletions in the $\varepsilon$-sarcoglycan gene (SGCE). Genetically characterised patients received bilateral DBS targeting the GPi, ${ }^{86-91}$ the thalamus (Vim) ${ }^{92} 93$ or both targets. $^{94} 95$ Stimulation of the Vim nucleus of the thalamus mainly improved the myoclonus ${ }^{96}$ rather than the dystonia, whereas bilateral GPi stimulation improved both. ${ }^{91} 95$ Other patients with genetically undocumented myoclonic dystonia were also improved by pallidal stimulation. ${ }^{18} 9798$ In the largest study $^{91}$ of genetically proven M-D, it appeared that both myoclonus and dystonia were improved by $60-90 \%$ with bilateral GPi stimulation (based on blinded evaluation of the BFM Dystonia Rating Scale and Unified Myoclonus Rating Scale). Similar benefits were also reported even in patients in the $6 \mathrm{th}^{93}$ or 7 th decades of life, ${ }^{91}$ with concomitant improvement in quality of life and no significant adverse events. One report has highlighted the risk of psychiatric side effects in patients with a SGCE mutation, treated with GPi-DBS. ${ }^{89}$

Taken together, these observations confirm the consistent motor improvement and acceptable safety of GPi stimulation in patients with M-D with SGCE mutation. This therapeutic option should therefore be considered for patients with severe 
Table 2 Myoclonus-dystonia (DYT11)

\begin{tabular}{|c|c|c|c|c|c|c|c|c|c|c|}
\hline \multirow[b]{2}{*}{ Localisation } & \multirow[b]{2}{*}{ Reference } & \multirow[b]{2}{*}{$\begin{array}{l}\text { Age at surgery } \\
\text { (years), median } \\
\text { (range) }\end{array}$} & \multirow[b]{2}{*}{$\begin{array}{l}\text { Duration of symptoms } \\
\text { (years), mean (range) }\end{array}$} & \multicolumn{3}{|l|}{ Dystonia } & \multicolumn{3}{|l|}{ Myoclonus } & \multirow[b]{2}{*}{$F / U$} \\
\hline & & & & $\begin{array}{l}\text { Pre-op severity } \\
\text { score, median } \\
\text { (range) }\end{array}$ & $\begin{array}{l}\text { Post-op severity } \\
\text { score, median } \\
\text { (range) }\end{array}$ & $\begin{array}{l}\% \text { Improvement } \\
\text { (range) }\end{array}$ & $\begin{array}{l}\text { Pre-op severity } \\
\text { score, median } \\
\text { (range) }\end{array}$ & $\begin{array}{l}\text { Post-op severity } \\
\text { score, median } \\
\text { (range) }\end{array}$ & $\begin{array}{l}\% \text { Improvement } \\
\text { (range) }\end{array}$ & \\
\hline \multirow[t]{7}{*}{ GPi } & $\begin{array}{l}\text { Azoulay-Zyss } \\
\text { et } a^{91} \\
n=5\end{array}$ & $42(30-71)$ & $26.4(18-65)$ & $\begin{array}{l}\text { BFM (mov) } \\
30.0 \text { (18.5-53.0) } \\
\text { BFM (dis) } \\
6(5-13)\end{array}$ & $\begin{array}{l}\text { BFM (mov) } \\
4.5(3.5-16.0) \\
\text { BFM (dis) } \\
2 \text { (2-6) }\end{array}$ & $\begin{array}{l}85 \%(70-91) \\
66.6 \%\end{array}$ & $\begin{array}{l}\text { UMRS (rest and } \\
\text { action) } \\
76(38-116)\end{array}$ & $\begin{array}{l}\text { UMRS (rest and } \\
\text { action) } \\
10(6-31)\end{array}$ & $83 \%(73-93)$ & $6-9$ months \\
\hline & $\begin{array}{l}\text { Papuc et } a l^{90} \\
\mathrm{n}=1\end{array}$ & 31 & 27 & BFM (mov)37 & $\begin{array}{l}\text { BFM (mov) } \\
14\end{array}$ & $62 \%$ & N/A & $\mathrm{N} / \mathrm{A}$ & N/A & 6 months \\
\hline & $\begin{array}{l}\text { Kurtis et } a l^{93} \\
\mathrm{n}=1\end{array}$ & 63 & 61 & $\begin{array}{l}\text { BFM (mov) } \\
38\end{array}$ & $\begin{array}{l}\text { BFM (mov) } \\
22.5\end{array}$ & $41 \%$ & N/A & $\mathrm{N} / \mathrm{A}$ & N/A & 14 months \\
\hline & $\begin{array}{l}\text { Jog et } a l^{88} \\
n=1\end{array}$ & 26 & 24 & $\begin{array}{l}\text { BFM (mov) } \\
12\end{array}$ & $\begin{array}{l}\text { BFM (mov) } \\
6\end{array}$ & $50 \%$ & $\begin{array}{l}\text { UMRS (tot) } \\
155\end{array}$ & $\begin{array}{l}\text { UMRS (tot) } \\
52\end{array}$ & $66.5 \%$ & 12 months \\
\hline & $\begin{array}{l}\text { Foncke et }\left.a\right|^{86} \\
n=2\end{array}$ & 39 & 36 & $\begin{array}{l}\text { BFM (mov) } \\
22\end{array}$ & $\begin{array}{l}\text { BFM (mov) } \\
9\end{array}$ & $59 \%$ & $\begin{array}{l}\text { UMRS (rest/action) } \\
42 / 38\end{array}$ & $\begin{array}{l}\text { UMRS (rest/action) } \\
2 / 8\end{array}$ & $95 \% / 79 \%$ & 6 months \\
\hline & & 18 & 11 & $\begin{array}{l}\text { BFM (mov) } \\
10\end{array}$ & $\begin{array}{l}\text { BFM (mov) } \\
4\end{array}$ & $60 \%$ & $\begin{array}{l}\text { UMRS (rest/action) } \\
18 / 30\end{array}$ & $\begin{array}{l}\text { UMRS (rest/action) } \\
4 / 3\end{array}$ & $78 \% / 90 \%$ & \\
\hline & $\begin{array}{l}\text { Cif et } a l^{87} \\
\mathrm{n}=1\end{array}$ & 8 & 7 & $\begin{array}{l}\text { BFM (mov) } \\
9.5 \\
\text { BFM (dis) } \\
9\end{array}$ & $\begin{array}{l}\text { BFM (mov) } \\
1.5 \\
\text { BFM (dis) } \\
1\end{array}$ & $\begin{array}{l}84 \% \\
89 \%\end{array}$ & $\begin{array}{l}\text { UMRS (tot/rest/ } \\
\text { action) } \\
69 / 16 / 20\end{array}$ & $\begin{array}{l}\text { UMRS (tot/rest/ } \\
\text { action) 13/1/2 }\end{array}$ & $81 \% / 94 \% / 90 \%$ & 20 months \\
\hline \multirow[t]{2}{*}{ Vim } & $\begin{array}{l}\text { Kuncel et } a l^{92} \\
\mathrm{n}=1\end{array}$ & 74 & $\mathrm{~N} / \mathrm{A}$ & $\mathrm{N} / \mathrm{A}$ & $\mathrm{N} / \mathrm{A}$ & N/A & N/A & $\mathrm{N} / \mathrm{A}$ & $\begin{array}{l}\text { UMRS (action) } \\
53 \% \\
\text { UMRS (funct) } \\
14 \%\end{array}$ & 9 months \\
\hline & $\begin{array}{l}\text { Trottenberg } \\
\text { et } a l^{96} \\
\mathrm{n}=1\end{array}$ & 60 & 54 & N/A & N/A & $\mathrm{N} / \mathrm{A}$ & $\begin{array}{l}\text { Myoclonus scale* } \\
116\end{array}$ & $\begin{array}{l}\text { Myoclonus scale* } \\
23\end{array}$ & $80 \%$ & 24 months \\
\hline
\end{tabular}

action, action subscore; BFM, Burke-Fahn-Marsden Dystonia Rating Scale; dis, disability subscore; ESRS, Extrapyramidal Symptom Rating Scale; F/U, follow-up; funct, functional subscore; GPi, internal globus pallidum; mov, movement subscc
of individuals in each study; N/A, not available; pre-op, preoperative state; post-op, postoperative state; rest, rest subscore; tot, total subscore; Vim, ventral internal, median nucleus of the thalamus; UMRS, Unified Myoclonus Rating Scale. 
forms of this disorder (table 2). The place of pallidal stimulation in patients with myoclonic dystonia with undocumented genetic status remains to be determined.

\section{Tardive dystonia (table 3)}

Among the first patients with this condition to be treated with bilateral thalamus (Vim) and GPi stimulation was a 70-year-old woman in whom bilateral GPi-DBS gave a clear and subsequently stable improvement in her painful dystonic syndrome within hours, although thalamus DBS was ineffective (table 3). ${ }^{99}$ Since then, single case reports and series have generally reported good results with GPi-DBS ${ }^{100}$ with occasional failures. $^{26}$ In 2007, a multicentre study confirmed the observations of earlier cases series. In 10 consecutive patients, the Extrapyramidal Symptoms Rating Scale (ESRS) was improved by $61 \%$ after surgery (range $44-75 \%$ ) in comparison with baseline. In the double-blind evaluation of the same patients, ESRS was $50 \%$ lower with stimulation than without stimulation. There were no changes in the patients' psychiatric status. ${ }^{101}$ In another report, a reduction in movement disorders by $80 \%$ has been observed, both on the motor and disability scores of the BFM and abnormal involuntary movement scales in addition to an improvement in quality of life. ${ }^{102}$ The extrapyramidal symptoms and dystonia improved rapidly after the DBS was switched on (sometimes within a few days). ${ }^{100} 103104$ The motor benefit has been observed to be sustained ${ }^{103} 105$ on mean follow-up of 41 (range $18-80$ ) months, ${ }^{102}$ up to a maximum of 8 years. ${ }^{106}$

The overall risk/benefit ratio of DBS in tardive dystonia is favourable, with no serious side effects being reported across the studies. In addition, affect also improved significantly, while cognitive functions remained unchanged compared with presurgical status on long-term follow-up. ${ }^{102} 105107$

\section{GPi-DBS and cognitive functions/quality of life}

There is little impact on cognitive function and behaviour with bilateral GPi-DBS in primary dystonia (generalised or segmental/cervical dystonia). ${ }^{7} 33$ 114-116 Some improvements have been reported, but this may be related to the reduction in dose of anticholinergic drugs, made possible by successful DBS treatment. There are some biases in these studies, as the patients were highly selected, with, at inclusion, normal cognitive performances and no mood disorders (patients with depression were excluded) at baseline. A list of preoperative tests on a routine basis is recommended, ${ }^{117}$ including the Wechsler Adult Intelligence Scale (WAIS) III in adults and Wechsler Intelligence Scale for Children (WISC) in children. In patients with primary dystonia, depression and anxiety scores remain stable.

Quality of life, assessed by the Short Form (36) Health Survey (SF36), shows improvement both in mental and physical categories. $^{115117118}$

\section{Dystonia with poor or less predictable favourable outcome Status dystonicus}

Status dystonicus is an acute and persistent combination of generalised dystonia and chorea. It represents an emergency and may occur in primary dystonia (including DYT1) or any kind of secondary dystonia including cerebral palsy, patients with PANK2 mutations, Wilson's disease and Batten disease. ${ }^{119}$ Common triggers for status dystonicus include general anaesthesia, the administration of metoclopramide, or infection and fever. The single cases and heterogeneous series reported ${ }^{116} 120$ suggest that GPi-DBS should be considered as a potential treatment in these life-threatening events (table 4), with improvement in pain and dystonia, ${ }^{120-123}$ although there may be a publication bias for cases with positive outcomes.

\section{Secondary dystonia}

We have focused on heredodegenerative and metabolic disorders (table 5). The issue of DBS for dystonia secondary to brain injury is strongly debated. ${ }^{108}$ Patients with secondary dystonia have complex movement disorders with a combination of hyperkinetic and akinetic-rigid dystonia. In addition, the targeted structure (DBS target) often has lesions, and the pathological process may be progressive (as in inherited metabolic disorders). Standardised assessment of global motor and functional outcomes (beyond the reduction of dystonia) is difficult because of the lack of adequate evaluation tools. However, the recent literature contains some reports of the benefit of this treatment in such patients.

In a pioneering controlled study of 13 patients with dystoniachoreoathetosis cerebral palsy due to neonatal hypoxic encephalopathy, GPi-DBS provoked a $24 \%$ decrease in the mean BFM motor score 12 months after surgery. ${ }^{82}$ Four patients improved by $39-55 \%$; four did not respond (improvement <20\%). Disability, mental health and body pain-related quality of life improved slightly. Several other case reports also suggested that GPi-DBS could offer a therapeutic alternative for dystonia due to various focal brain lesions and inherited metabolic or genetic disorders. There is evidence to suggest that GPi-DBS may be effective in patients with PANK2 mutations (average motor improvement of 30\%, although with marked variability). ${ }^{129} 135134137$ Anecdotal reports also indicate that GPi-DBS could be useful in patients with dystonia secondary to GM1 gangliosidosis, ${ }^{150}$ mitochondrial disorder with striatal necrosis, ${ }^{151}$ Lesch-Nyhan disease ${ }^{138} 145144152$ and X-linked parkinsonism. ${ }^{153}$ As the literature is sparse, the selection of patients for DBS in secondary dystonia is highly challenging, and cases should be discussed by a multidisciplinary team on an individual basis. Our experience and literature review suggest that three aspects must be considered: (i) the clinical picture (GPi stimulation may be more effective on hyperkinetic movement disorders); (ii) the distribution of the brain lesions; and (iii) careful evaluation of the functional aim and the patient's expectations.

\section{SAFETY: LONG-TERM SIDE EFFECTS}

In addition to well-established hardware-related (such as infection, haemorrhage, leads or extension fractures) and stimulation-related (dysarthria) side effects, some unusual deleterious effects have been reported in a few dystonic patients chronically treated with GPi-DBS. Acquired stuttering was described in two patients under conditions that optimally suppressed dystonic symptoms, with marked disability in one case. ${ }^{154}$ Parkinsonism was also reported in patients with cranialcervical dystonia. ${ }^{155} 156$ Hypokinetic gait disorder and freezing of gait ${ }^{157}$ in dystonia are not related to electrode misplacement. A shuffling gait and difficulties with gait initiation may be triggered by voltage increases, while modification of other variables such as pulse width or frequency does not seem to help much. A compromise between optimal stimulation for dystonia and undesirable effects such as freezing of gait must be obtained.

Mood disorders should be carefully assessed, given reports of postoperative suicide. ${ }^{158} 159$ Patients with mild to moderate depression, including patients with history of depression (tardive dystonia) appear to do well after the operation. However, there are few data on patients with severe mood disorders (active depression is currently an exclusion criterion for surgery). Screening and management strategies before and after surgery are available for patients identified as having a major psychiatric illness. ${ }^{117}$ 


\begin{tabular}{|c|c|c|c|c|c|c|c|}
\hline Reference & $\begin{array}{l}\text { Age at surgery } \\
\text { (years), } \\
\text { mean (range) }\end{array}$ & $\begin{array}{l}\text { Disease duration } \\
\text { (years), } \\
\text { mean (range) }\end{array}$ & $\begin{array}{l}\text { Stimulationparameters } \\
\mathrm{R} / \mathrm{L}\end{array}$ & $\begin{array}{l}\text { Pre-op } \\
\text { severityscore, } \\
\text { mean (range) }\end{array}$ & $\begin{array}{l}\text { Post-op } \\
\text { severityscore, } \\
\text { mean (range) }\end{array}$ & $\begin{array}{l}\% \text { Improvementat } \\
\text { last F/U }\end{array}$ & F/U \\
\hline $\begin{array}{l}\text { Chang et } a l^{106} \\
\mathrm{n}=5\end{array}$ & $57.8(28-59)$ & $10.6(6-20)$ & $\begin{array}{l}3.14 \pm 0.5 \mathrm{~V} / 2.9 \pm 0.45 \mathrm{~V} \\
204 \pm 13.4 / 198 \pm 16.4 \mu \mathrm{s} \\
130 \pm 56 \mathrm{~Hz}\end{array}$ & $\begin{array}{l}\text { BFM (mov) } \\
47.9 \\
\text { BFM (dis) } \\
11.8\end{array}$ & $\begin{array}{l}\text { BFM (mov) } \\
14.5 \\
\text { BFM (dis) } \\
6.2\end{array}$ & $\begin{array}{l}70.9 \pm 12 \% \\
47.9 \pm 18 \%\end{array}$ & $\begin{array}{l}34 \text { months (15-76) } \\
\text { median (range) }\end{array}$ \\
\hline $\begin{array}{l}\text { Capelle et } a l^{107} \\
\mathrm{n}=4\end{array}$ & 45 & 4 & $\begin{array}{l}\text { gr parameters } \\
4.5 \mathrm{~V}(3.0-6.5) \\
90-210 \mu \mathrm{s} \\
130-160 \mathrm{~Hz}\end{array}$ & $\begin{array}{l}\text { BFM (mov) } \\
65 \\
\text { BFM (dis) } \\
8\end{array}$ & $\begin{array}{l}\text { BFM (mov) } \\
5.5 \\
\text { BFM (dis) } \\
1\end{array}$ & $\begin{array}{l}91 \% \\
88 \%\end{array}$ & 27 months \\
\hline & 76 & 11 & & $\begin{array}{l}55 \\
6\end{array}$ & $\begin{array}{l}16 \\
3\end{array}$ & $\begin{array}{l}70 \% \\
50 \%\end{array}$ & 30 months \\
\hline & 65 & 7 & & $\begin{array}{l}18 \\
1\end{array}$ & $\begin{array}{l}2 \\
0\end{array}$ & $\begin{array}{l}88 \% \\
100 \%\end{array}$ & 16 months \\
\hline & 48 & 5 & & $\begin{array}{l}33 \\
8\end{array}$ & $\begin{array}{l}4.5 \\
4\end{array}$ & $\begin{array}{l}87 \% \\
50 \%\end{array}$ & 36 months \\
\hline $\begin{array}{l}\text { Gruber et } a l^{102} \\
n=9\end{array}$ & $63.2(38-76)$ & $5.3(2-11)$ & $\begin{array}{l}3.0 \pm 1.0 \mathrm{~V} / 2.8 \pm 0.6 \mathrm{~V} \\
83.3 \pm 13.2 \mu \mathrm{s} \\
154 \pm 25.1 \mathrm{~Hz}\end{array}$ & $\begin{array}{l}- \\
- \\
-\end{array}$ & $\begin{array}{l}- \\
- \\
-\end{array}$ & $\begin{array}{l}\text { BFM (mov) } \\
83 \pm 12.2 \% \\
\text { BFM (dis) } \\
67.7 \pm 28 \% \\
\text { AIMS } \\
78.7 \pm 19.9 \%\end{array}$ & $\begin{array}{l}41 \text { months (18-80) } \\
\text { mean (range) }\end{array}$ \\
\hline $\begin{array}{l}\text { Katsakiori et al }{ }^{108} \\
\mathrm{n}=1\end{array}$ & 40 & 3 & N/A & $\begin{array}{l}\text { BFM (mov) } \\
35 \\
\text { BFM (dis) } \\
19\end{array}$ & $\begin{array}{l}\text { BFM (mov) } \\
2 \\
\text { BFM (dis) } \\
3\end{array}$ & $\begin{array}{l}94 \% \\
84 \%\end{array}$ & 12 months \\
\hline $\begin{array}{l}\text { Kefalopoulou et al }{ }^{109} \\
n=1\end{array}$ & 42 & 3 & $\begin{array}{l}2.5-3.6 \mathrm{~V} \\
250-400 \mu \mathrm{s} \\
185 \mathrm{~Hz}\end{array}$ & $\begin{array}{l}\text { BFM (mov) } \\
52 \\
\text { AIMS } \\
30\end{array}$ & $\begin{array}{l}\text { BFM (mov) } \\
4.5 \\
\text { AIMS } \\
7\end{array}$ & $\begin{array}{l}91 \% \\
77 \%\end{array}$ & 6 months \\
\hline $\begin{array}{l}\text { Magarinos-Ascone } \\
\text { et } \mathrm{al}^{110} \\
\mathrm{n}=1\end{array}$ & 59 & 4 & N/A & $\begin{array}{l}\text { BFM (mov) } \\
46 \\
\text { BFM (dis) } \\
16\end{array}$ & $\begin{array}{l}\text { BFM (mov) } \\
24 \\
\text { BFM (dis) } \\
9\end{array}$ & $\begin{array}{l}48 \% \\
44 \%\end{array}$ & 12 months \\
\hline $\begin{array}{l}\text { Sako et } a l^{105} \\
n=6\end{array}$ & $44.5(31-64)$ & $3.1(0.5-6)$ & $\begin{array}{l}2.2 \pm 0.9 \mathrm{~V} \\
450 \mu \mathrm{s} \\
119 \pm 28 \mathrm{~Hz}\end{array}$ & & $\begin{array}{ll}- \\
-\end{array}$ & $\begin{array}{l}\text { BFM (mov) } \\
86 \pm 14 \% \\
\text { BFM (dis) } \\
80 \pm 12 \%\end{array}$ & 21 months \\
\hline $\begin{array}{l}\text { Pretto et al }{ }^{111} \\
\mathrm{n}=1\end{array}$ & 72 & N/A & $\begin{array}{l}4.0 \mathrm{~V} \\
90 \mu \mathrm{s} \\
185 \mathrm{~Hz}\end{array}$ & & $\begin{array}{l}\text { BFM (mov) } \\
1\end{array}$ & $90 \%$ & 3 months \\
\hline
\end{tabular}

Continued 
Table 3 Continued

\begin{tabular}{|c|c|c|c|c|c|c|c|}
\hline Reference & $\begin{array}{l}\text { Age at surgery } \\
\text { (years), } \\
\text { mean (range) }\end{array}$ & $\begin{array}{l}\text { Disease duration } \\
\text { (years), } \\
\text { mean (range) }\end{array}$ & $\begin{array}{l}\text { Stimulationparameters } \\
\mathrm{R} / \mathrm{L}\end{array}$ & $\begin{array}{l}\text { Pre-op } \\
\text { severityscore, } \\
\text { mean (range) }\end{array}$ & $\begin{array}{l}\text { Post-op } \\
\text { severityscore, } \\
\text { mean (range) }\end{array}$ & $\begin{array}{l}\% \text { Improvementat } \\
\text { last F/U }\end{array}$ & $F / U$ \\
\hline \multirow[t]{2}{*}{$\begin{array}{l}\text { Cohen et al }{ }^{104} \\
\mathrm{n}=2\end{array}$} & 44 & 4 & $\begin{array}{l}4 \mathrm{~V} \\
90 \mu \mathrm{s} \\
130 \mathrm{~Hz}\end{array}$ & & $\begin{array}{l}\text { BFM (mov) } \\
3 \\
\text { BFM (dis) } \\
0\end{array}$ & $\begin{array}{l}86 \% \\
100 \%\end{array}$ & 13 months \\
\hline & 50 & 4 & $\begin{array}{l}4 \mathrm{~V} \\
120 \mu \mathrm{s} \\
130 \mathrm{~Hz}\end{array}$ & $\begin{array}{l}31.5 \\
19\end{array}$ & $\begin{array}{l}11.5 \\
9\end{array}$ & $\begin{array}{l}64 \% \\
53 \%\end{array}$ & 7 months \\
\hline $\begin{array}{l}\text { Damier et a }\left.\right|^{112} \\
\mathrm{n}=10\end{array}$ & $45.1(26-69)$ & $4.5(1-10)$ & $\begin{array}{l}3.5 \pm 0.2 v \\
150 \mu \mathrm{s} \\
130 \mathrm{~Hz}\end{array}$ & $\begin{array}{l}- \\
-\end{array}$ & $\begin{array}{l}- \\
-\end{array}$ & $\begin{array}{l}\text { ESRS } \\
61 \%(44-75) \\
\text { AIMS } \\
56 \%(33-69)\end{array}$ & 6 months \\
\hline \multirow[t]{2}{*}{$\begin{array}{l}\text { Starr et a }\left.\right|^{27} \\
\mathrm{n}=4\end{array}$} & 36 & 7 & $\mathrm{~N} / \mathrm{A}$ & $\begin{array}{l}\text { BFM (mov) } \\
11\end{array}$ & $\begin{array}{l}\text { BFM (mov) } \\
0\end{array}$ & $100 \%$ & 26 months \\
\hline & $\begin{array}{l}47 \\
59 \\
36\end{array}$ & $\begin{array}{l}4 \\
20 \\
10\end{array}$ & $\begin{array}{l}\text { N/A } \\
\text { N/A } \\
\text { N/A }\end{array}$ & $\begin{array}{l}38 \\
57 \\
80\end{array}$ & $\begin{array}{l}7.5 \\
53.5 \\
37.5\end{array}$ & $\begin{array}{l}80 \% \\
6 \% \\
53 \%\end{array}$ & $\begin{array}{l}27 \text { months } \\
17 \text { months } \\
9 \text { months }\end{array}$ \\
\hline $\begin{array}{l}\text { Zhang et } a /^{113} \\
\mathrm{n}=1\end{array}$ & 28 & 3 & $\begin{array}{l}\text { STN bilat } \\
1.5 \mathrm{~V} / 3.0 \mathrm{~V} \\
90 \mu \mathrm{s} \\
185 \mathrm{~Hz}\end{array}$ & $\begin{array}{l}\text { BFM (mov) } \\
98.5 \\
\text { UDRS } \\
94\end{array}$ & $\begin{array}{l}\text { BFM (mov) } \\
8 \\
\text { UDRS } \\
7.5\end{array}$ & $\begin{array}{l}92 \% \\
92 \%\end{array}$ & 3 months \\
\hline \multirow[t]{2}{*}{$\begin{array}{l}\text { Franzini et al }{ }^{100} \\
n=2\end{array}$} & 33 & 5 & $\begin{array}{l}1 \mathrm{~V} \\
90 \mu \mathrm{s} \\
130 \mathrm{~Hz}\end{array}$ & $\begin{array}{l}\text { BFM (mov) } \\
36\end{array}$ & $\begin{array}{l}\text { BFM (mov) } \\
5\end{array}$ & $86 \%$ & 12 months \\
\hline & 30 & 3 & $\begin{array}{l}1 \mathrm{~V} \\
90 \mu \mathrm{s} \\
130 \mathrm{~Hz}\end{array}$ & 70 & 8 & $89 \%$ & 13 months \\
\hline $\begin{array}{l}\text { Trottenberg et } \mathrm{al}^{103} \\
\mathrm{n}=5\end{array}$ & $56.2(30-70)$ & $\mathrm{N} / \mathrm{A}$ & $\begin{array}{l}2.7 \pm 0.8 \mathrm{~V} \\
111 \pm 57 \mu \mathrm{s} \\
144 \pm 22 \mathrm{~Hz}\end{array}$ & $\begin{array}{l}\text { BFM (mov) } \\
32 \\
\text { BFM (dis) } \\
8\end{array}$ & $\begin{array}{l}- \\
-\end{array}$ & $\begin{array}{l}87 \% \\
96 \%\end{array}$ & 6 months \\
\hline $\begin{array}{l}\text { Krause et } a l^{26} \\
\mathrm{n}=2\end{array}$ & 53.7 & 5.7 & $\mathrm{~N} / \mathrm{A}$ & $\begin{array}{l}\text { BFM (mov) } \\
62\end{array}$ & $\begin{array}{l}\text { BFM (mov) } \\
63.5\end{array}$ & $-2 \%$ & 30 months \\
\hline & 47.6 & 22.6 & $\mathrm{~N} / \mathrm{A}$ & 76 & 77 & $-1 \%$ & 42 months \\
\hline $\begin{array}{l}\text { Eltahawy et } a l^{20} \\
\mathrm{n}=1\end{array}$ & 53 & 4 & $\begin{array}{l}2.6 \mathrm{~V} \\
210 \mu \mathrm{s} \\
40 \mathrm{~Hz}\end{array}$ & $\begin{array}{l}\text { BFM (mov) } \\
52\end{array}$ & $\begin{array}{l}\text { BFM (mov) } \\
21\end{array}$ & $60 \%$ & 18 months \\
\hline $\begin{array}{l}\text { Yianni et } a l^{18} \\
\mathrm{n}=1\end{array}$ & 40 & 5 & $\mathrm{~N} / \mathrm{A}$ & $\begin{array}{l}\text { AIMS } \\
24\end{array}$ & $\begin{array}{l}\text { AIMS } \\
14\end{array}$ & $42 \%$ & 12 months \\
\hline
\end{tabular}

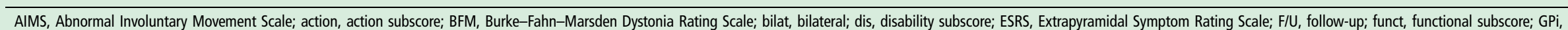

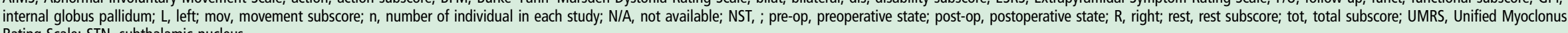
Rating Scale; STN, subthalamic nucleus. 
Table 4 Status dystonicus

\begin{tabular}{|c|c|c|c|c|c|c|c|c|}
\hline Reference & $\begin{array}{l}\text { Age } \\
\text { (years)/ } \\
\text { sex }\end{array}$ & Aetiology & Precipitating factor & Surgery & $\begin{array}{l}\text { Delay in } \\
\text { improvement }\end{array}$ & Outcome & $F / U$ & Complications \\
\hline $\begin{array}{l}\text { Walcott } \\
\text { et } \mathrm{al}^{123} \\
\mathrm{n}=3\end{array}$ & $\begin{array}{l}14 / \mathrm{M} \\
9 / \mathrm{F} \\
9 / \mathrm{F}\end{array}$ & $\begin{array}{l}\text { Kernicterus } \\
\text { perinatal/CP } \\
\text { Generalised } \\
\text { dystonia } \\
\text { CP }\end{array}$ & $\begin{array}{l}\text { Spinal surgery } \\
\text { Unknown } \\
\text { Upper respiratory illness }\end{array}$ & $\begin{array}{l}\text { GPi bilat } \\
\text { GPi bilat } \\
\text { GPi bilat }\end{array}$ & $\begin{array}{l}\text { Few days } \\
\text { Few weeks } \\
\text { Few weeks }\end{array}$ & $\begin{array}{l}+ \\
+ \\
(\mathrm{R} \text { side }) \\
+\end{array}$ & $\begin{array}{l}12 \text { months } \\
3 \text { months } \\
3 \text { months }\end{array}$ & $\begin{array}{l}\text { L lower contact } \\
\text { partially working } \\
\text { Infection } \\
\text { (explantation R) } \\
\text { None }\end{array}$ \\
\hline $\begin{array}{l}\text { Kovacs } \\
\text { et } a l^{124} \\
n=1\end{array}$ & 18/M & Tardive dystonia & No apparent & GPi bilat & Few days & $\begin{array}{l}\text { BFM pre-op (mov/dis) } \\
108 / 28 \\
\text { BFM post-op } 2 \text { weeks } \\
42 / 18 \\
\text { BFM post-op } 1 \text { year } \\
3.5 / 1\end{array}$ & 12 months & None \\
\hline $\begin{array}{l}\text { Grandas } \\
\text { et } \text { al }^{125} \\
\mathrm{n}=1\end{array}$ & $19 / \mathrm{M}$ & NBIA (PANK2) & No apparent & GPi bilat & Few days & $\begin{array}{l}\text { BFM pre-op (mov/dis) } \\
96 / 29 \\
\text { BFM post-op } 9 \text { months } \\
10 / 4\end{array}$ & 9 months & None \\
\hline $\begin{array}{l}\text { Apetauerova } \\
\text { et } a l^{116} \\
n=2\end{array}$ & $\begin{array}{l}16 / \mathrm{M} \\
26 / \mathrm{M}\end{array}$ & $\begin{array}{l}\mathrm{CP} \\
\mathrm{CP}\end{array}$ & $\begin{array}{l}\text { Surgery/metoclopramide } \\
\text { surgery }\end{array}$ & $\begin{array}{l}\text { GPi bilat } \\
\text { GPi bilat }\end{array}$ & $\begin{array}{l}\text { Few hours } \\
\text { Few days }\end{array}$ & $\begin{array}{l}+ \\
\text { (Returned to baseline } \\
\text { functional status) } \\
+ \\
\text { (Returned to baseline } \\
\text { functional status) }\end{array}$ & $\begin{array}{l}30 \text { months } \\
34 \text { months }\end{array}$ & $\begin{array}{l}\text { None } \\
\text { None }\end{array}$ \\
\hline $\begin{array}{l}\text { Jech et } a l^{126} \\
n=1\end{array}$ & $12 / \mathrm{M}$ & $\begin{array}{l}\text { Generalised } \\
\text { dystonia }\end{array}$ & No apparent & GPi bilat & Few weeks & $\begin{array}{l}\text { BFM pre-op (mov) } \\
41 \\
\text { BFM post-op } 2 \text { months } \\
5 \\
\text { BFM } \\
\text { post-op15 months } \\
3\end{array}$ & 15 months & None \\
\hline $\begin{array}{l}\text { Elkay et } a l^{119} \\
\mathrm{n}=1\end{array}$ & $19 / F$ & Batten's disease & No apparent & $\begin{array}{l}\text { Pallidotomy } \\
\text { GPi bilat }\end{array}$ & Few days & $\begin{array}{l}\text { BFM (mov) off stim } \\
100 \\
\text { BFM on stim } \\
62\end{array}$ & 7 months & None \\
\hline $\begin{array}{l}\text { Mariotti } \\
\text { et } a l^{122} \\
n=1\end{array}$ & $15 / \mathrm{M}$ & NBIA (PANK2) & $\begin{array}{l}\text { Recurrent infection } \\
\text { (upper respiratory } \\
\text { illness/pneumonia) }\end{array}$ & GPi bilat* & $\mathrm{N} / \mathrm{A}$ & $\begin{array}{l}+ \\
\text { No recurrence of } \\
\text { status dystonicus }\end{array}$ & 12 months & None \\
\hline $\begin{array}{l}\text { Teive et } a l^{121} \\
n=1\end{array}$ & $57 / M$ & $\begin{array}{l}\text { Generalised } \\
\text { dystonia }\end{array}$ & Stress & GPi bilat & $N / A$ & ++ & $\mathrm{N} / \mathrm{A}$ & $\begin{array}{l}\text { Mild L } \\
\text { hemiparesis }\end{array}$ \\
\hline $\begin{array}{l}\text { Zorzi et } a l^{21} \\
n=3\end{array}$ & $\begin{array}{l}8.2 / \mathrm{M} \\
14.2 / \mathrm{M} \\
10.6 / \mathrm{M}\end{array}$ & $\begin{array}{l}\text { Generalised } \\
\text { dystonia } \\
\text { Encephalopathy } \\
\text { unknown origin } \\
\text { Generalised } \\
\text { dystonia }\end{array}$ & $\begin{array}{l}\text { Upper respiratory illness } \\
\text { No apparent } \\
\text { No apparent }\end{array}$ & $\begin{array}{l}\text { GPi bilat } \\
\text { GPi bilat } \\
\text { GPi bilat }\end{array}$ & $\begin{array}{l}\text { Few months } \\
\text { Few days } \\
\text { Few days }\end{array}$ & $\begin{array}{l}\text { BFM pre-op (mov/dis) } \\
91 / 20 \\
\text { BFM post-op at last } \\
\text { F/U } \\
83 / 19 \\
\text { BFM pre-op (mov/dis) } \\
43 / 12 \\
\text { BFM post-op at last } \\
\text { F/U } \\
43 / 12 \\
\text { BFM pre-op (mov/dis) } \\
79.5 / 19 \\
\text { BFM post-op at last } \\
\text { F/U } \\
63 / 10\end{array}$ & $\begin{array}{l}15 \text { months } \\
15 \text { months } \\
19 \text { months }\end{array}$ & $\begin{array}{l}\text { Unpredictable } \\
\text { switching off } \\
\text { None† } \\
\text { Unpredictable } \\
\text { switching off }\end{array}$ \\
\hline $\begin{array}{l}\text { Angelini } \\
\text { et }\left.a\right|^{127} \\
n=1\end{array}$ & $13 / \mathrm{M}$ & $\begin{array}{l}\text { Unknown } \\
\text { TH deficiency? }\end{array}$ & $\mathrm{N} / \mathrm{A}$ & GPi bilat & Few days & + & 7 months & None \\
\hline
\end{tabular}

${ }^{*}$ DBS performed some months after the status dystonicus and not in an emergency situation.

tReimplantation procedure after an infection 2 years ago.

action, action subscore; BFM, Burke-Fahn-Marsden Dystonia Rating Scale; bilat, bilateral; CP, cerebral palsy; DBS, deep brain stimulation; dis, disability subscore; F, female; F/U, follow-up; funct, functional subscore; GPi, internal globus pallidum; L, left; $M$, male; mov, movement subscore; $n$, number of individuals in each study; N/A, not available; pre-op, preoperative state; post-op, postoperative state; $\mathrm{R}$, right; stim, stimulation; $\mathrm{TH}$, tyrosine hydroxylase; $=$ no improvement; $+=$ good outcome; $++=$ excellent outcome (according to outcome described by the authors). 
Table 5 Secondary dystonia: neurodegenerative and metabolic disorders

\begin{tabular}{|c|c|c|c|c|c|c|c|}
\hline Subtype & Reference & $\begin{array}{l}\text { Age at surgery } \\
\text { (years), } \\
\text { mean (range) }\end{array}$ & $\begin{array}{l}\text { Disease duration } \\
\text { (years), } \\
\text { mean (range) }\end{array}$ & $\begin{array}{l}\text { Pre-op severity } \\
\text { score, } \\
\text { mean (range) }\end{array}$ & $\begin{array}{l}\text { Post-op severity } \\
\text { score, } \\
\text { mean (range) }\end{array}$ & $\begin{array}{l}\% \\
\text { Improvement }\end{array}$ & $F / U$ \\
\hline \multicolumn{8}{|l|}{ Heredodegenerative } \\
\hline NBIA & 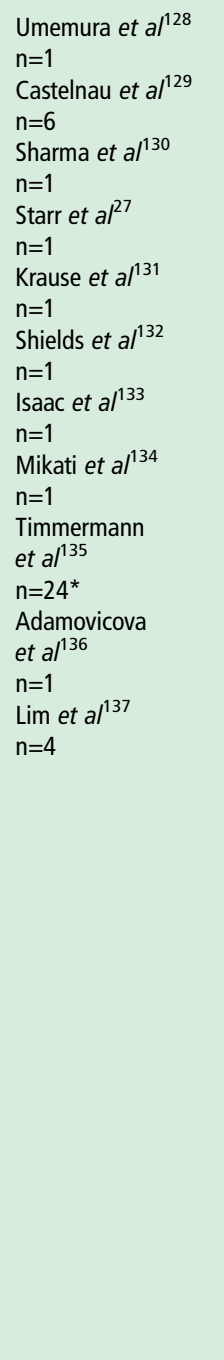 & $\begin{array}{l}36 \\
21(10-39) \\
8 \\
43 \\
13 \\
17 \\
16 \\
11 \\
18(6-36) \\
17.5 \\
\text { N/A } \\
\text { N/A } \\
\text { N/A } \\
\text { N/A }\end{array}$ & $\begin{array}{l}28 \\
10(2-22) \\
2 \\
13 \\
7 \\
8 \\
10 \\
8.5 \\
10.2(3-28) \\
8.5 \\
\text { N/A } \\
\text { N/A } \\
\text { N/A } \\
\text { N/A }\end{array}$ & $\begin{array}{l}\text { BFM (mov) } \\
112 \\
\text { BFM (mov) } \\
75.1 \text { (45.5-102) } \\
\text { BFM (dis) } \\
20 \text { (7-30) } \\
\text { N/A } \\
\text { BFM (mov) } \\
30 \\
\text { BFM (mov) } \\
92 \\
\text { BFM (mov) } \\
86 \\
\text { BFM (mov) } \\
105 \\
\text { Barry-Albright } \\
\text { Dystonia Scale } \\
24 \\
71.2 \text { (21-112) } \\
77.5 \\
\text { BFM (mov) } \\
96 \\
79.5 \\
44.5 \\
46\end{array}$ & $\begin{array}{l}\text { BFM (mov) } \\
22.5 \\
\text { BFM (mov) } \\
20.1 \text { (5.5-46.5) } \\
\text { BFM (dis) } \\
9.7 \text { (3-23) } \\
\text { N/A } \\
\text { BFM (mov) } \\
6 \\
\text { BFM (mov) at } \\
1 \text { year } \\
30 \\
\text { BFM (mov) at } \\
5 \text { years } \\
70 \\
\text { BFM (mov) } \\
66 \\
\text { BFM (mov) } \\
72 \\
\text { Barry-Albright } \\
\text { Dystonia Scale } \\
8 \\
\text { N/A } \\
15 \\
22.5 \\
38 \\
\text { BFM (mov) at } \\
3 \text { months } \\
69 \\
\text { BFM (mov) at } 6 \text { m } \\
74.5 \\
\text { BFM (mov) at } \\
12 \text { months } \\
\text { N/A } \\
79.5 \\
72 \\
80 \\
44.5 \\
24 \\
38 \\
56 \\
43.5 \\
39 \\
\end{array}$ & $\begin{array}{l}80 \% \\
74.6 \% \text { (46- } \\
91.5 \% \text { ) } \\
53 \%(21-82) \\
\text { None } \\
\\
80 \% \\
70 \% \\
24 \% \\
23 \% \\
31 \% \\
66.7 \% \\
\text { FU1 } \\
28.5 \% \\
\text { FU2 } \\
25.7 \% \\
81 \% \\
71 \% \\
51 \% \\
28 \% \\
22 \% \\
\text { N/A } \\
0 \% \\
9.5 \% \\
0 \% \\
0 \% \\
46 \% \\
15 \% \\
-22 \% \\
5.4 \% \\
15 \%\end{array}$ & $\begin{array}{l}12 \text { months } \\
20.6 \text { months } \\
(6-42) \\
\text { Death } \\
\text { at } 3 \text { months } \\
12 \text { months } \\
5 \text { years } \\
\text { N/A } \\
24 \text { months } \\
\text { Infection } \\
\text { at } 3 \text { months } \\
\text { F/U1 } \\
2-6 \text { months } \\
\text { F/U2 } \\
9-15 \text { months } \\
4.5 \text { years } \\
6 \text { months } \\
12 \text { months } \\
12 \text { months } \\
12 \text { months }\end{array}$ \\
\hline Lesch-Nyhan & $\begin{array}{l}\text { Cif et } a l^{138} \\
\mathrm{n}=1 \\
\text { Deon et } a l^{139} \\
\mathrm{n}=1\end{array}$ & $\begin{array}{l}16 \\
8\end{array}$ & $\begin{array}{l}15 \\
7\end{array}$ & $\begin{array}{l}\text { BFM (mov) } \\
78.5 \\
\text { N/A }\end{array}$ & $\begin{array}{l}\text { BFM (mov) } \\
46.5 \\
\text { N/A }\end{array}$ & $\begin{array}{l}41 \% \\
\text { BFM (mov) } \\
50 \%\end{array}$ & $\begin{array}{l}28 \text { months } \\
30 \text { months }\end{array}$ \\
\hline Cockayne syndrome & $\begin{array}{l}\text { Hamasaki et a }\left.\right|^{140} \\
\mathrm{n}=1\end{array}$ & 52 & 22 & $\begin{array}{l}\text { BFM (mov) } \\
45\end{array}$ & $\begin{array}{l}\text { BFM (mov) } \\
19.5\end{array}$ & $56.7 \%$ & 5 months \\
\hline Dystonia deafness & $\begin{array}{l}\text { Havrankova et } \mathrm{al}^{141} \\
\mathrm{n}=1\end{array}$ & 29 & 5 & $\begin{array}{l}\text { BFM (mov) } \\
53\end{array}$ & $\begin{array}{l}\text { BFM (mov) } \\
13\end{array}$ & $75 \%$ & 10 months \\
\hline $\begin{array}{l}\text { Lubag X-linked dystonia } \\
\text { parkinsonism }\end{array}$ & $\begin{array}{l}\text { Evidente et } a l^{142} \\
\mathrm{n}=1 \\
\text { Martinez-Torres } \\
\text { et } a l^{143} \\
\mathrm{n}=1 \\
\text { Oyama et } a l^{144} \\
\mathrm{n}=1 \\
\text { Wadia et } a l^{145} \\
\mathrm{n}=1 \\
\text { Aguilar et } a l^{146} \\
\mathrm{n}=1\end{array}$ & $\begin{array}{l}45 \\
34 \\
66 \\
39 \\
32\end{array}$ & $\begin{array}{l}1 \\
9 \\
3\end{array}$ & $\begin{array}{l}\text { BFM (mov) } \\
\text { UPDRS } \\
40 \\
33 \\
77.5 \\
37 \\
48 \\
14 \\
87 \\
40 \\
40.5 \\
9.5\end{array}$ & $\begin{array}{l}\text { BFM (mov) } \\
\text { UPDRS } \\
9.5 \\
8 \\
15 \\
8 \\
43 \\
4.5 \\
17 \\
38 \\
4.75 \\
4\end{array}$ & $\begin{array}{l}76.3 \% \\
75.8 \% \\
80.6 \% \\
78.4 \% \\
10.4 \% \\
67.9 \% \\
80.4 \% \\
5 \% \\
88.3 \% \\
57.9 \%\end{array}$ & $\begin{array}{l}12 \text { months } \\
12 \text { months } \\
12 \text { months } \\
12 \text { months } \\
12 \text { months }\end{array}$ \\
\hline $\begin{array}{l}\text { Rapid-onset dystonia } \\
\text { parkinsonism }\end{array}$ & $\begin{array}{l}\text { Deutschlander } \\
\text { et } a l^{147} \\
\mathrm{n}=1\end{array}$ & $\begin{array}{l}21 \\
24\end{array}$ & $\begin{array}{l}2 \\
12\end{array}$ & $\begin{array}{l}\text { BFM (mov) } \\
50 \\
\text { BFM (mov) } \\
55.5\end{array}$ & $\begin{array}{l}\text { BFM (mov) } \\
50 \\
\text { BFM (mov) } \\
41\end{array}$ & $\begin{array}{l}0 \% \\
26 \% \\
3.2 \%\end{array}$ & $\begin{array}{l}27 \text { months } \\
12 \text { months }\end{array}$ \\
\hline
\end{tabular}


Table 5 Continued

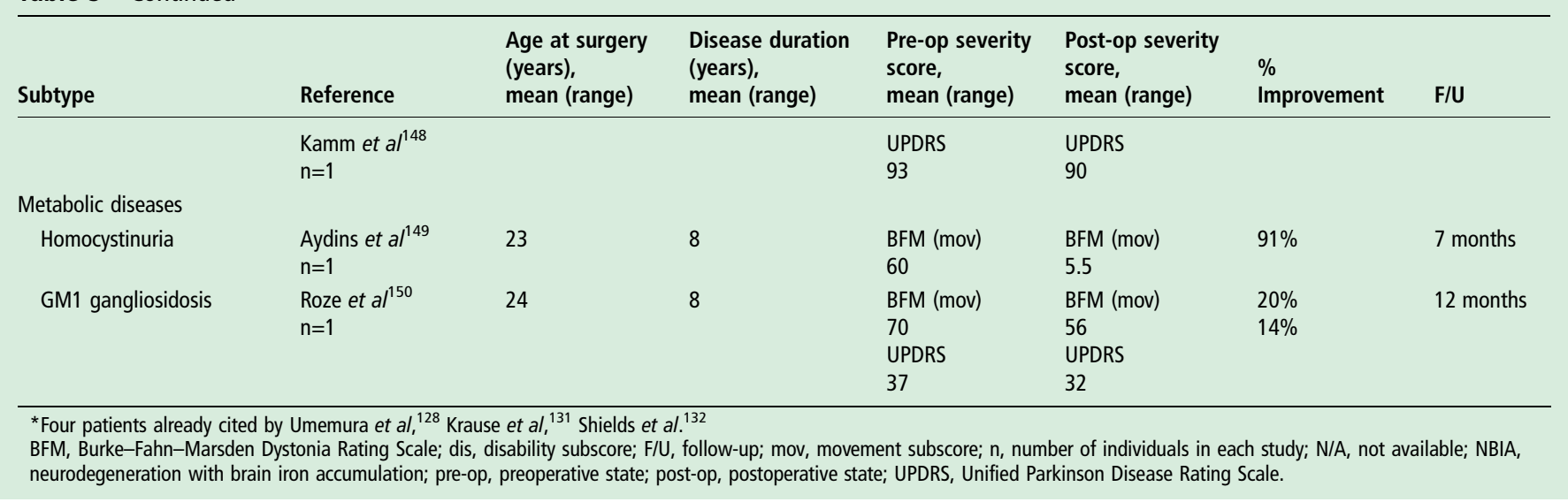

\section{CURRENT PRACTICE AND LEADS FOR THE FUTURE}

Beside the checklist of exclusion criteria, ${ }^{160}$ the preoperative assessment aims to characterise the severity of dystonia and to evaluate the mood, cognition and quality of life. Detailed description of preoperative selection, ${ }^{160}$ evaluation ${ }^{161} 117$ and postoperative management ${ }^{162}$ is beyond the scope of this review and is fully detailed in the Movement Disorders Journal supplement (2011) dedicated to the management of DBS in dystonia.

Although the decision may appear relatively easy and straightforward for primary dystonia, myoclonus-dystonia and tardive dystonia, reliable tools to help accurate prediction of postoperative beneficial effects and the time course of improvement are still lacking.

Several authors have made detailed recommendations about DBS in the treatment of adult dystonia, ${ }^{10}{ }^{15}$ but paediatric guidelines are lacking, mainly because of the absence of controlled studies in this age group. Management of DBS in childhood dystonia differs in several aspects from that of DBS in dystonic adults: (i) childhood dystonia is more often secondary than primary; (ii) mixed motor disorders are common (eg, dystonia associated with spasticity); (iii) the course of dystonia may be influenced by ongoing brain maturation and by the plasticity of the brain; (iv) the therapeutic strategy must be discussed with both the patient and his/her parents ; and (vi) the child's education must be taken into account. In addition, the overall incidence of wound breakdown and hardware infection requiring device removal seems to be higher in children than in adults. ${ }^{16} 163$

As in adults, there is no reliable way of predicting outcome for a given subject. Although not specifically studied in the paediatric population, pallidal DBS is also a relevant option in children with severe medically refractory myoclonus-dystonia syndrome. ${ }^{87}$ However, the possibility of spontaneous improvement in dystonia during childhood ${ }^{164}$ in this setting should be considered during discussion of the therapeutic strategy, especially when DBS is being considered.

In secondary dystonia, the main challenge is to determine which evaluation tool to use to capture any functional benefit in DBS. The BFM dystonia scale, the gold standard scale used in therapeutic trials for dystonia, may fail to measure subtle but relevant clinical effects of DBS on the child's participation in everyday activities. In this context, the goals of DBS may be more related to improving comfort and quality of life rather than motor function per se, even in the absence of significant change in BFM severity subscore. ${ }^{165}$

\section{CONCLUSION}

GPi-DBS has long-term efficacy and safety in severe primary generalised and cervical dystonia but late unusual complications such as akinesia or freezing of gait may rarely occur. Tardive dystonia or myoclonus dystonia may also represent good indications. Clinical predictive factors of favourable outcome for GPi-DBS in dystonia have emerged in the past few years, but there is a need for more reliable markers that will help to accurately select dystonic patients who will benefit from DBS. Alternative targets have been recently proposed, with variable beneficial effects of subthalamic stimulation in cervical dystonia, ${ }^{166}$ but with a risk of adverse effects such as weight gain or transient dyskinesia.

Acknowledgements We would like to acknowledge APHP (Assistance Publique-Hôpitaux de Paris) and DRRC (Direction Recherche Clinique), who funded our studies, and the support of the patient's associations, Alliance France Dystonie and AMADYS (Association des Malades Atteints de Dystonie).

Contributors All the authors were involved in the conception, drafting and critical revision of this review.

\section{Competing interests None.}

Provenance and peer review Commissioned; externally peer reviewed.

\section{REFERENCES}

1 Mundinger F. Neue stereotaktisch-funktionelle Behandlungsmethode des Torticollis spasmodicus mit Hirnstimulatoren. Med Klin 1977;72:1982-6.

2 Benabid AL, Pollak P, Louveau A, et al. Combined (thalamotomy and stimulation) stereotactic surgery of the VIM thalamic nucleus for bilateral Parkinson disease. App/ Neurophysiol 1987;50:344-6.

3 Krauss JK, Pohle T, Weber $\mathrm{S}$, et al. Bilateral stimulation of globus pallidus internus for treatment of cervical dystonia. Lancet 1999:354:837-8.

4 Kumar R, Dagher A, Hutchison WD, et al. Globus pallidus deep brain stimulation for generalized dystonia: clinical and PET investigation. Neurology 1999;53:871-4.

5 Coubes $P$, Roubertie A, Vayssiere N, et al. Treatment of DYT1-generalised dystonia by stimulation of the internal globus pallidus. Lancet 2000;355:2220-1.

6 Vidailhet M, Vercueil L, Houeto JL, et al. Bilateral deep-brain stimulation of the globus pallidus in primary generalized dystonia. N Engl J Med 2005;352:459-67.

7 Kupsch A, Benecke R, Muller J, et al. Pallidal deep-brain stimulation in primary generalized or segmental dystonia. N Engl J Med 2006;355:1978-90.

8 Kiss ZH, Doig-Beyaert K, Eliasziw M, et al. The Canadian multicentre study of deep brain stimulation for cervical dystonia. Brain 2007;130:2879-86.

9 Welter ML, Grabli D, Vidailhet M. Deep brain stimulation for hyperkinetics disorders: dystonia, tardive dyskinesia, and tics. Curr Opin Neurol 2010;23:420-5.

10 Andrews C, Aviles-Olmos I, Hariz M, et al. Which patients with dystonia benefit from deep brain stimulation? A metaregression of individual patient outcomes. J Neurol Neurosurg Psychiatry 2010;81:1383-9.

11 Bronte-Stewart H. Surgical therapy for dystonia. Curr Neurol Neurosci Rep 2003;3:296-305.

12 Alterman RL, Snyder BJ. Deep brain stimulation for torsion dystonia. Acta Neurochir Supp/ 2007;97:191-9. 
13 Hamani C, Moro E, Zadikoff $C$, et al. Location of active contacts in patients with primary dystonia treated with globus pallidus deep brain stimulation. Neurosurgery 2008:62:217-23; discussion 23-5.

14 Cif L, Vasques X, Gonzalez V, et al. Long-term follow-up of DYT1 dystonia patients treated by deep brain stimulation: An open-label study. Mov Disord 2010;25:289-99

15 Albanese A, Asmus F, Bhatia KP, et al. EFNS guidelines on diagnosis and treatment of primary dystonias. Eur I Neurol 2011;18:5-18.

16 Air EL, Ostrem JL, Sanger TD, et al. Deep brain stimulation in children: experience and technical pearls. J Neurosurg Pediatr 2011;8:566-74.

17 Vesper J, Klostermann F, Funk T, et al. Deep brain stimulation of the globus pallidus internus (GPI) for torsion dystonia - a report of two cases. Acta Neurochir Supp/ 2002;79:83-8

18 Yianni J, Bain P, Giladi N, et al. Globus pallidus internus deep brain stimulation for dystonic conditions: a prospective audit. Mov Disord 2003;18:436-42.

19 Cif L, El Fertit $\mathrm{H}$, Vayssiere $\mathrm{N}$, et al. Treatment of dystonic syndromes by chronic electrical stimulation of the internal globus pallidus. J Neurosurg Sci 2003:47:52-5.

20 Eltahawy HA, Saint-Cyr J, Giladi N, et al. Primary dystonia is more responsive than secondary dystonia to pallidal interventions: outcome after pallidotomy or pallidal deep brain stimulation. Neurosurgery 2004;54:613-19; discussion 9-21.

21 Zorzi G, Marras C, Nardocci N, et al. Stimulation of the globus pallidus internus for childhood-onset dystonia. Mov Disord 2005;20:1194-200.

22 Diamond A, Shahed J, Azher S, et al. Globus pallidus deep brain stimulation in dystonia. Mov Disord 2006;21:692-5.

23 Tisch S, Rothwell JC, Bhatia KP, et al. Pallidal stimulation modifies after-effects of paired associative stimulation on motor cortex excitability in primary generalised dystonia. Exp Neurol 2007;206:80-5.

24 Egidi M, Franzini A, Marras C, et al. A survey of Italian cases of dystonia treated by deep brain stimulation. J Neurosurg Sci 2007;51:153-8.

25 Isaias IU, Alterman RL, Tagliati M. Deep brain stimulation for primary generalized dystonia: long-term outcomes. Arch Neurol 2009;66:465-70.

26 Krause $M$, Fogel $W$, Kloss $M$, et al. Pallidal stimulation for dystonia. Neurosurgery 2004:55:1361-8; discussion 8-70.

27 Starr PA, Turner RS, Rau G, et al. Microelectrode-guided implantation of deep brain stimulators into the globus pallidus internus for dystonia: techniques, electrode locations, and outcomes. J Neurosurg 2006;104:488-501.

28 Loher TJ, Capelle HH, Kaelin-Lang A, et al. Deep brain stimulation for dystonia: outcome at long-term follow-up. J Neurol 2008:255:881-4.

29 Valldeoriola F, Regidor I, Minguez-Castellanos A, et al. Efficacy and safety of pallidal stimulation in primary dystonia: results of the Spanish multicentric study. J Neurol Neurosurg Psychiatry 2010;81:65-9.

30 Bereznai B, Steude U, Seelos K, et al. Chronic high-frequency globus pallidus internus stimulation in different types of dystonia: a clinical, video, and MRI report of six patients presenting with segmental, cervical, and generalized dystonia. Mov Disord 2002;17:138-44.

31 Krauss JK. Deep brain stimulation for cervical dystonia. J Neurol Neurosurg Psychiatry 2003;74:1598.

32 Bittar RG, Yianni J, Wang $\mathrm{S}$, et al. Deep brain stimulation for generalised dystonia and spasmodic torticollis. J Clin Neurosci 2005;12:12-16.

33 Hung SW, Hamani C, Lozano AM, et al. Long-term outcome of bilateral pallidal deep brain stimulation for primary cervical dystonia. Neurology 2007:68:457-9.

34 Jeong SG, Lee MK, Kang JY, et al. Pallidal deep brain stimulation in primary cervical dystonia with phasic type : clinical outcome and postoperative course. J Korean Neurosurg Soc 2009;46:346-50.

35 Sarubbo S, Latini F, Quatrale R, et al. Five-year follow-up of 10 patients treated with globus pallidus internus deep brain stimulation for segmental or multisegmental dystonia. Stereotact Funct Neurosurg 2012;90:84-91.

36 Cacciola F, Farah JO, Eldridge PR, et al. Bilateral deep brain stimulation for cervical dystonia: long-term outcome in a series of 10 patients. Neurosurgery 2010:67:957-63.

37 Skogseid IM, Ramm-Pettersen J, Volkmann J, et al. Good long-term efficacy of pallidal stimulation in cervical dystonia: a prospective, observer-blinded study. Eur J Neurol 2012;19:610-15.

38 Cif L, Gonzalez-Martinez V, Vasques X, et al. Staged implantation of multiple electrodes in the internal globus pallidus in the treatment of primary generalized dystonia. J Neurosurg 2012;116:1144-52.

39 Saleh C. How effective is GPi-DBS in the treatment of Meige's syndrome? Parkinsonism Relat Disord 2011:17:569.

40 Tai $\mathrm{CH}$, Wu RM, Liu HM, et al. Meige syndrome relieved by bilateral pallidal stimulation with cycling mode: case report. Neurosurgery 2011;69:E1333-7.

41 Limotai N, Go C, Oyama G, et al. Mixed results for GPi-DBS in the treatment of cranio-facial and cranio-cervical dystonia symptoms. J Neurol 2011;258:2069-74.

42 Foote KD, Sanchez JC, Okun MS. Staged deep brain stimulation for refractory craniofacial dystonia with blepharospasm: case report and physiology. Neurosurgery 2005:56:E415; discussion E.

43 Batla A, Stamelou M, Bhatia KP. Treatment of Focal Dystonia. Curr Treat Options Neurol 2012.
44 Houser M, Waltz T. Meige syndrome and pallidal deep brain stimulation. Mov Disord 2005;20:1203-5.

45 Ostrem JL, Marks WJ Jr, Volz MM, et al. Pallidal deep brain stimulation in patients with cranial-cervical dystonia (Meige syndrome). Mov Disord 2007;22:1885-91.

46 Blomstedt $\mathrm{P}$, Hariz $\mathrm{MI}$, Tisch S, et al. A family with a hereditary form of torsion dystonia from northern Sweden treated with bilateral pallidal deep brain stimulation. Mov Disord 2009;24:2415-19.

47 Lyons MK, Birch BD, Hillman RA, et al. Long-term follow-up of deep brain stimulation for Meige syndrome. Neurosurg Focus 2010;29:E5.

48 Markaki E, Kefalopoulou Z, Georgiopoulos M, et al. Meige's syndrome: A cranial dystonia treated with bilateral pallidal deep brain stimulation. Clin Neurol Neurosurg 2010;112:344-6.

49 Romito LM, Elia AE, Franzini A, et al. Low-voltage bilateral pallidal stimulation for severe meige syndrome in a patient with primary segmental dystonia: case report. Neurosurgery 2010;67:onsE308; discussion onsE.

50 Ghang JY, Lee MK, Jun SM, et al. Outcome of pallidal deep brain stimulation in meige syndrome. J Korean Neurosurg Soc 2010;48:134-8.

51 Sensi M, Cavallo MA, Quatrale R, et al. Pallidal stimulation for segmental dystonia: long term follow up of 11 consecutive patients. Mov Disord 2009;24:1829-35.

52 Reese R, Gruber D, Schoenecker T, et al. Long-term clinical outcome in meige syndrome treated with internal pallidum deep brain stimulation. Mov Disord 2011:26:691-8

53 Sako W, Morigaki R, Mizobuchi Y, et al. Bilateral pallidal deep brain stimulation in primary Meige syndrome. Parkinsonism Relat Disord 2011:17:123-5.

54 Inoue N, Nagahiro $S$, Kaji R, et al. Long-term suppression of Meige syndrome after pallidal stimulation: a 10-year follow-up study. Mov Disord 2010;25:1756-8.

55 Blomstedt $\mathrm{P}$, Tisch S, Hariz Ml. Pallidal deep brain stimulation in the treatment of Meige syndrome. Acta Neurol Scand 2008;118:198-202.

56 Opherk C, Gruber C, Steude U, et al. Successful bilateral pallidal stimulation for Meige syndrome and spasmodic torticollis. Neurology 2006;66:E14.

57 Capelle HH, Weigel R, Krauss JK. Bilateral pallidal stimulation for blepharospasm-oromandibular dystonia (Meige syndrome). Neurology 2003:60:2017-18

58 Vercueil L, Pollak P, Fraix V, et al. Deep brain stimulation in the treatment of severe dystonia. J Neurol 2001;248:695-700.

59 Muta D, Goto S, Nishikawa S, et al. Bilateral pallidal stimulation for idiopathic segmental axial dystonia advanced from Meige syndrome refractory to bilateral thalamotomy. Mov Disord 2001;16:774-7.

60 Goto S, Shimazu H, Matsuzaki K, et al. Thalamic Vo-complex vs pallidal deep brain stimulation for focal hand dystonia. Neurology 2008:70:1500-1.

61 Cho CB, Park HK, Lee KJ, et al. Thalamic Deep Brain Stimulation for Writer's Cramp. J Korean Neurosurg Soc 2009:46:52-5.

62 Goto S, Yamada K. Long term continuous bilateral pallidal stimulation produces stimulation independent relief of cervical dystonia. J Neurol Neurosurg Psychiatry 2004;75:1506-7.

63 Taira T, Ochiai T, Goto S, et al. Multimodal neurosurgical strategies for the management of dystonias. Acta Neurochir Supp/ 2006;99:29-31.

64 Morishita T, Foote KD, Haq IU, et al. Should we consider Vim thalamic deep brain stimulation for select cases of severe refractory dystonic tremor. Stereotact Funct Neurosurg 2010;88:98-104

65 Zittel S, Moll CK, Hamel W, et al. Successful GPi deep brain stimulation in a patient with adult onset primary axial dystonia. I Neurol Neurosurg Psychiatry 2009:80:811-12.

66 Woehrle JC, Blahak C, Kekelia K, et al. Chronic deep brain stimulation for segmental dystonia. Stereotact Funct Neurosurg 2009;87:379-84.

67 Low HL, Honey CR. Focal childhood-onset, action induced primary hip dystonia treated with pallidal deep brain stimulation. Mov Disord 2008;23:1926-8.

68 Isaias IU, Alterman RL, Tagliati M. Outcome predictors of pallidal stimulation in patients with primary dystonia: the role of disease duration. Brain 2008;131:1895-902

69 Isaias IU, Volkmann J, Kupsch A, et al. Factors predicting protracted improvement after pallidal DBS for primary dystonia: the role of age and disease duration. J Neurol 2011;258:1469-76.

70 Borggraefe I, Mehrkens JH, Telegravciska $\mathrm{M}$, et al. Bilateral pallidal stimulation in children and adolescents with primary generalized dystonia-report of six patients and literature-based analysis of predictive outcomes variables. Brain Dev 2010:32:223-8.

71 Groen JL, Ritz K, Contarino MF, et al. DYT6 dystonia: mutation screening phenotype, and response to deep brain stimulation. Mov Disord 2010;25:2420-7.

72 Panov F, Tagliati M, Ozelius LJ, et al. Pallidal deep brain stimulation for DYT6 dystonia. J Neurol Neurosurg Psychiatry 2012:83:182-7.

73 Ruge D, Cif L, Limousin $P$, et al. Shaping reversibility? Long-term deep brain stimulation in dystonia: the relationship between effects on electrophysiology and clinical symptoms. Brain 2011;134:2106-15.

74 Ruge D, Tisch S, Hariz Ml, et al. Deep brain stimulation effects in dystonia: time course of electrophysiological changes in early treatment. Mov Disord 2011:26:1913-21. 
75 Hebb MO, Chiasson $\mathrm{P}$, Lang $\mathrm{AE}$, et al. Sustained relief of dystonia following cessation of deep brain stimulation. Mov Disord 2007;22:1958-62.

76 Grabli D, Ewenczyk C, Coelho-Braga MC, et al. Interruption of deep brain stimulation of the globus pallidus in primary generalized dystonia. Mov Disord 2009:24:2363-9.

77 Anheim M, Vercueil L, Fraix V, et al. Early stimulation of DYT1 primary generalized dystonia prevents from its secondary irreversible complications. Mov Disord 2008:23:2261-3.

78 Guettard E, Ricard D, Roze E, et al. Risk factors for spinal cord lesions in dystonic cerebral palsy and generalised dystonia. J Neurol Neurosurg Psychiatry 2012;83:159-63.

79 Krauss JK, Loher TJ, Pohle T, et al. Pallidal deep brain stimulation in patients with cervical dystonia and severe cervical dyskinesias with cervical myelopathy. J Neurol Neurosurg Psychiatry 2002;72:249-56.

80 Tisch S, Zrinzo L, Limousin P, et al. Effect of electrode contact location on clinical efficacy of pallidal deep brain stimulation in primary generalised dystonia. J Neurol Neurosurg Psychiatry 2007;78:1314-19.

81 Houeto JL, Yelnik J, Bardinet E, et al. Acute deep-brain stimulation of the internal and external globus pallidus in primary dystonia: functional mapping of the pallidum. Arch Neurol 2007;64:1281-6.

82 Vidailhet M, Yelnik J, Lagrange C, et al. Bilateral pallidal deep brain stimulation for the treatment of patients with dystonia-choreoathetosis cerebral palsy: a prospective pilot study. Lancet Neurol 2009;8:709-17.

83 Kleiner-Fisman G, Liang GS, Moberg PJ, et al. Subthalamic nucleus deep brain stimulation for severe idiopathic dystonia: impact on severity, neuropsychological status, and quality of life. J Neurosurg 2007;107:29-36.

84 Vasques $X$, Cif $L$, Hess 0 , et al. Prognostic value of globus pallidus internus volume in primary dystonia treated by deep brain stimulation. $J$ Neurosurg $2009 ; 110: 220-8$

85 Vasques $X$, Cif $L$, Hess 0 , et al. Stereotactic model of the electrical distribution within the internal globus pallidus during deep brain stimulation. J Comput Neurosci 2009;26:109-18.

86 Foncke EM, Bour LJ, Speelman JD, et al. Local field potentials and oscillatory activity of the internal globus pallidus in myoclonus-dystonia. Mov Disord 2007;22:369-76

87 Cif L, Valente EM, Hemm S, et al. Deep brain stimulation in myoclonus-dystonia syndrome. Mov Disord 2004;19:724-7

88 Jog M, Kumar H. Bilateral pallidal deep brain stimulation in a case of myoclonus dystonia syndrome. Mov Disord 2009;24:1547-9.

89 Contarino MF, Foncke EM, Cath DC, et al. Effect of pallidal deep brain stimulation on psychiatric symptoms in myoclonus-dystonia due to epsilon-sarcoglycan mutations. Arch Neurol 2011;68:1087-8; author reply 8-9.

90 Papuc E, Obszanska K, Rejdak K, et al. Atypical symptomatology of myoclonus dystonia (DYT-11) with positive response to bilateral pallidal deep brain stimulation. Mov Disord 2011 (In press).

91 Azoulay-Zyss J, Roze E, Welter ML, et al. Bilateral deep brain stimulation of the pallidum for myoclonus-dystonia due to epsilon-sarcoglycan mutations: a pilot study. Arch Neurol 2011;68:94-8.

92 Kuncel AM, Turner DA, Ozelius LJ, et al. Myoclonus and tremor response to thalamic deep brain stimulation parameters in a patient with inherited myoclonus-dystonia syndrome. Clin Neurol Neurosurg 2009;111:303-6.

93 Kurtis MM, San Luciano M, Yu Q, et al. Clinical and neurophysiologica improvement of SGCE myoclonus-dystonia with GPi deep brain stimulation. Clin Neurol Neurosurg 2010;112:149-52.

94 Oropilla JQ, Diesta CC, Itthimathin P, et al. Both thalamic and pallidal deep brain stimulation for myoclonic dystonia. J Neurosurg 2010:112:1267-70.

95 Gruber D, Kuhn AA, Schoenecker T, et al. Pallidal and thalamic deep brain stimulation in myoclonus-dystonia. Mov Disord 2010;25:1733-43.

96 Trottenberg T, Meissner W, Kabus C, et al. Neurostimulation of the ventral intermediate thalamic nucleus in inherited myoclonus-dystonia syndrome. Mov Disord 2001;16:769-71.

97 Liu X, Griffin IC, Parkin SG, et al. Involvement of the medial pallidum in foca myoclonic dystonia: a clinical and neurophysiological case study. Mov Disord 2002;17:346-53.

98 Magarinos-Ascone CM, Regidor I, Martinez-Castrillo JC, et al. Pallidal stimulation relieves myoclonus-dystonia syndrome. J Neurol Neurosurg Psychiatry 2005;76:989-91.

99 Trottenberg T, Paul G, Meissner W, et al. Pallidal and thalamic neurostimulation in severe tardive dystonia. J Neurol Neurosurg Psychiatry 2001;70:557-9.

100 Franzini A, Marras C, Ferroli $P$, et al. Long-term high-frequency bilateral pallidal stimulation for neuroleptic-induced tardive dystonia. Report of two cases. J Neurosurg 2005;102:721-5.

101 Thobois S, Poisson A, Damier P. Surgery for tardive dyskinesia. Int Rev Neurobiol 2011:98:289-96.

102 Gruber D, Trottenberg T, Kivi A, et al. Long-term effects of pallidal deep brain stimulation in tardive dystonia. Neurology 2009;73:53-8.

103 Trottenberg T, Volkmann J, Deuschl G, et al. Treatment of severe tardive dystonia with pallidal deep brain stimulation. Neurology 2005;64:344-6.
104 Cohen OS, Hassin-Baer S, Spiegelmann R. Deep brain stimulation of the internal globus pallidus for refractory tardive dystonia. Parkinsonism Relat Disord 2007:13:541-4.

105 Sako W, Goto S, Shimazu H, et al. Bilateral deep brain stimulation of the globus pallidus internus in tardive dystonia. Mov Disord 2008;23:1929-31.

106 Chang EF, Schrock LE, Starr PA, et al. Long-term benefit sustained after bilateral pallidal deep brain stimulation in patients with refractory tardive dystonia. Stereotact Funct Neurosurg 2010;88:304-10.

107 Capelle HH, Blahak C, Schrader C, et al. Chronic deep brain stimulation in patients with tardive dystonia without a history of major psychosis. Mov Disord 2010;25:1477-81

108 Katsakiori PF, Kefalopoulou Z, Markaki E, et al. Deep brain stimulation fo secondary dystonia: results in 8 patients. Acta Neurochir (Wien) 2009;151:473-8; discussion 8.

109 Kefalopoulou Z, Paschali A, Markaki E, et al. A double-blind study on a patient with tardive dyskinesia treated with pallidal deep brain stimulation. Acta Neurol Scand 2009;119:269-73

110 Magarinos-Ascone CM, Regidor I, Gomez-Galan M, et al. Deep brain stimulation in the globus pallidus to treat dystonia: electrophysiological characteristics and 2 years' follow-up in 10 patients. Neuroscience 2008;152:558-71.

111 Pretto TE, Dalvi A, Kang UJ, et al. A prospective blinded evaluation of deep brain stimulation for the treatment of secondary dystonia and primary torticollis syndromes. J Neurosurg 2008;109:405-9.

112 Damier $\mathrm{P}$, Thobois S, Witjas T, et al. Bilateral deep brain stimulation of the globus pallidus to treat tardive dyskinesia. Arch Gen Psychiatry 2007;64:170-6.

113 Zhang JG, Zhang K, Wang ZC. Deep brain stimulation in the treatment of tardive dystonia. Chin Med J 2006;119:789-92.

114 Thobois S, Ballanger B, Xie-Brustolin J, et al. Globus pallidus stimulation reduces frontal hyperactivity in tardive dystonia. J Cereb Blood Flow Metab 2008:28:1127-38.

115 Pillon B, Ardouin C, Dujardin K, et al. Preservation of cognitive function in dystonia treated by pallidal stimulation. Neurology 2006;66:1556-8.

116 Apetauerova D, Schirmer CM, Shils JL, et al. Successful bilateral deep brain stimulation of the globus pallidus internus for persistent status dystonicus and generalized chorea. J Neurosurg 2010;113:634-8.

117 Jahanshahi M, Czernecki V, Zurowski AM. Neuropsychological, neuropsychiatric and quality of life issues in DBS for dystonia. Mov Disord 2011;26(Suppl 1):S63-78.

118 Halbig TD, Gruber D, Kopp UA, et al. Pallidal stimulation in dystonia: effects on cognition, mood, and quality of life. J Neurol Neurosurg Psychiatry 2005; 76:1713-16.

119 Elkay M, Silver K, Penn RD, et al. Dystonic storm due to Batten's disease treated with pallidotomy and deep brain stimulation. Mov Disord 2009;24:1048-53.

120 Balas I, Kovacs N, Hollody K. Staged bilateral stereotactic pallidothalamotomy for life-threatening dystonia in a child with Hallervorden-Spatz disease. Mov Disord 2006:21:82-5.

121 Teive HA, Munhoz RP, Souza MM, et al. Status Dystonicus: study of five cases Arq Neuropsiquiatr 2005;63:26-9.

122 Mariotti P, Fasano A, Contarino MF, et al. Management of status dystonicus: our experience and review of the literature. Mov Disord 2007;22:963-8.

123 Walcott BP, Nahed BV, Kahle KT, et al. Deep brain stimulation for medically refractory life-threatening status dystonicus in children. J Neurosurg Pediatr 2012;9:99-102.

124 Kovacs N, Balas I, Janszky J, et al. Status dystonicus in tardive dystonia successfully treated by bilateral deep brain stimulation. Clin Neurol Neurosurg 2011;113:808-9.

125 Grandas F, Fernandez-Carballal C, Guzman-de-Villoria J, et al. Treatment of a dystonic storm with pallidal stimulation in a patient with PANK2 mutation. Mov Disord 2011:26:921-2.

126 Jech R, Bares M, Urgosik D, et al. Deep brain stimulation in acute management of status dystonicus. Mov Disord 2009;24:2291-2.

127 Angelini L, Nardocci N, Estienne M, et al. Life-threatening dystonia-dyskinesias in a child: successful treatment with bilateral pallidal stimulation. Mov Disord 2000;15:1010-12.

128 Umemura A, Jaggi JL, Dolinskas CA, et al. Pallidal deep brain stimulation for longstanding severe generalized dystonia in Hallervorden-Spatz syndrome. Case report. J Neurosurg 2004;100:706-9.

129 Castelnau P, Cif L, Valente EM, et al. Pallidal stimulation improves pantothenate kinase associated neurodegeneration. Ann Neurol 2005;57:738-41.

130 Sharma MC, Aggarwal N, Bihari M, et al. Hallervorden spatz disease: MR and pathological findings of a rare case. Neurology India 2005;53:102-4.

131 Krause M, Fogel W, Tronnier $V$, et al. Long-term benefit to pallidal deep brain stimulation in a case of dystonia secondary to pantothenate kinase-associated neurodegeneration. Mov Disord 2006;21:2255-7.

132 Shields DC, Sharma N, Gale JT, et al. Pallidal stimulation for dystonia in pantothenate kinase-associated neurodegeneration. Pediatr Neurol 2007:37:442-5

133 Isaac C, Wright I, Bhattacharyya D, et al. Pallidal stimulation for pantothenate kinase-associated neurodegeneration dystonia. Arch Dis Childhood 2008:93:239-40. 
134 Mikati MA, Yehya A, Darwish $\mathrm{H}$, et al. Deep brain stimulation as a mode of treatment of early onset pantothenate kinase-associated neurodegeneration. Eur J Paediatr Neurol 2009;13:61-4.

135 Timmermann L, Pauls KA, Wieland K, et al. Dystonia in neurodegeneration with brain iron accumulation: outcome of bilateral pallidal stimulation. Brain 2010;133:701-12

136 Adamovicova $M$, Jech $R$, Urgosik D, et al. Pallidal stimulation in siblings with pantothenate kinase-associated neurodegeneration: four-year follow-up. Mov Disord 2011;26:184-7.

137 Lim BC, Ki CS, Cho A, et al. Pantothenate kinase-associated neurodegeneration in Korea: recurrent R440P mutation in PANK2 and outcome of deep brain stimulation. Eur J Neurol 2012;19:556-61.

138 Cif L, Biolsi B, Gavarini S, et al. Antero-ventral internal pallidum stimulation improves behavioral disorders in Lesch-Nyhan disease. Mov Disord 2007;22:2126-9.

139 Deon LL, Kalichman MA, Booth $\mathrm{CL}$, et al. Pallidal deep-brain stimulation associated with complete remission of self-injurious behaviors in a patient with Lesch-Nyhan syndrome: a case report. J Child Neurology 2012;27:117-20.

140 Hamasaki K, Yamada K, Hamasaki T, et al. GPi-pallidal stimulation to treat generalized dystonia in Cockayne syndrome. Mov Disord 2010;25:656-8.

141 Havrankova $\mathrm{P}$, Jech R, Roth J, et al. Beneficial effect of deep brain stimulation of GPi in a patient with dystonia-deafness phenotype. Mov Disord 2009;24:465-6.

142 Evidente VG, Lyons MK, Wheeler $M$, et al. First case of X-linked dystoniaparkinsonism ("Lubag") to demonstrate a response to bilateral pallidal stimulation. Mov Disord 2007:22:1790-3.

143 Martinez-Torres I, Limousin P, Tisch S, et al. Early and marked benefit with GPi DBS for Lubag syndrome presenting with rapidly progressive life-threatening dystonia. Mov Disord 2009;24:1710-12.

144 Oyama G, Fernandez HH, Foote KD, et al. Differential response of dystonia and parkinsonism following globus pallidus internus deep brain stimulation in X-linked dystonia-parkinsonism (Lubag). Stereotact Funct Neurosurg 2010;88:329-33.

145 Wadia PM, Lim SY, Lozano AM, et al. Bilateral pallidal stimulation for x-linked dystonia parkinsonism. Arch Neurol 2010;67:1012-15.

146 Aguilar JA, Vesagas TS, Jamora RD, et al. The promise of deep brain stimulation in X-linked dystonia parkinsonism. Int J Neurosci 2011;121(Suppl 1):57-63.

147 Deutschlander A, Asmus F, Gasser T, et al. Sporadic rapid-onset dystonia-parkinsonism syndrome: failure of bilateral pallidal stimulation. Mov Disord 2005;20:254-7.

148 Kamm C, Fogel W, Wachter T, et al. Novel ATP1A3 mutation in a sporadic RDP patient with minimal benefit from deep brain stimulation. Neurology 2008:70:1501-3

149 Aydin S, Abuzayed B, Varlibas F, et al. Treatment of homocystinuria-related dystonia with deep brain stimulation: a case report. Stereotact Funct Neurosurg 2011;89:210-13.
150 Roze E, Navarro S, Cornu P, et al. Deep brain stimulation of the globus pallidus for generalized dystonia in GM1 Type 3 gangliosidosis: technical case report. Neurosurgery 2006;59:E1340; discussion E.

151 Aniello MS, Martino D, Petruzzella V, et al. Bilateral striatal necrosis, dystonia and multiple mitochondrial DNA deletions: case study and effect of deep brain stimulation. Mov Disord 2008;23:114-18.

152 Martinez-Torres I, Hariz MI, Zrinzo L, et al. Improvement of tics after subthalamic nucleus deep brain stimulation. Neurology 2009;72:1787-9.

153 Kemmotsu N, Price CC, Oyama G, et al. Pre- and post- GPi DBS neuropsychological profiles in a case of X-linked dystonia-Parkinsonism. Clin Neuropsychol 2011;25:141-59.

154 Nebel A, Reese R, Deuschl G, et al. Acquired stuttering after pallidal deep brain stimulation for dystonia. J Neural Transm 2009;116:167-9.

155 Zauber SE, Watson N, Comella CL, et al. Stimulation-induced parkinsonism after posteroventral deep brain stimulation of the globus pallidus internus for craniocervical dystonia. J Neurosurg 2009;110:229-33.

156 Berman BD, Starr PA, Marks WJ Jr, et al. Induction of bradykinesia with pallidal deep brain stimulation in patients with cranial-cervical dystonia. Stereotact Funct Neurosurg 2009;87:37-44.

157 Schrader C, Capelle HH, Kinfe TM, et al. GPi-DBS may induce a hypokinetic gait disorder with freezing of gait in patients with dystonia. Neurology 2011;77:483-8.

158 Ghika J, Villemure JG, Miklossy J, et al. Postanoxic generalized dystonia improved by bilateral Voa thalamic deep brain stimulation. Neurology 2002;58: 311-13.

159 Foncke EM, Schuurman PR, Speelman JD. Suicide after deep brain stimulation of the internal globus pallidus for dystonia. Neurology 2006;66:142-3.

160 Bronte-Stewart $H$, Taira T, Valldeoriola F, et al. Inclusion and exclusion criteria for DBS in dystonia. Mov Disord 2011;26(Suppl 1):S5-16.

161 Thobois S, Guillouet S, Broussolle E. Contributions of PET and SPECT to the understanding of the pathophysiology of Parkinson's disease. Neurophysiol Clin 2001;31:321-40.

162 Kupsch A, Tagliati M, Vidailhet M, et al. Early postoperative management of DBS in dystonia: programming, response to stimulation, adverse events, medication changes, evaluations, and troubleshooting. Mov Disord 2011;26(Suppl 1):S37-53.

163 Haridas A, Tagliati M, Osborn I, et al. Pallidal deep brain stimulation for primary dystonia in children. Neurosurgery 2011;68:738-43; discussion 43.

164 Kinugawa K, Vidailhet M, Clot F, et al. Myoclonus-dystonia: an update. Mov Disord 2009:24:479-89.

165 Gimeno H, Tustin K, Selway R, et al. Beyond the Burke-Fahn-Marsden Dystonia Rating Scale: Deep brain stimulation in childhood secondary dystonia. Eur J Paediatr Neurol 2012;16:501-8.

166 Ostrem JL, Racine CA, Glass GA, et al. Subthalamic nucleus deep brain stimulation in primary cervical dystonia. Neurology 2011;76:870-8. 